\title{
Impaired Actions of Insulin-like Growth Factor 1 on Protein Synthesis and Degradation in Skeletal Muscle of Rats with Chronic Renal Failure Evidence for a Postreceptor Defect
}

\author{
Hu Ding, ${ }^{*}$ Xiu-Lin Gao, ${ }^{\star}$ Raimund Hirschberg, ${ }^{\star}$ Jaydutt V. Vadgama, ${ }^{\ddagger}$ and Joel D. Kopple* \\ *Division of Nephrology and Hypertension, Harbor-UCLA Medical Center, Torrance, California 90509, and the UCLA Schools of \\ Medicine and Public Health, Los Angeles, California 90032; and ${ }^{\ddagger}$ Department of Medicine, Charles R. Drew University of Medicine and \\ Science, Los Angeles, California 90059
}

\begin{abstract}
The actions of insulin-like growth factor 1 (IGF-1) on protein turnover and of the IGF-1 receptor (IGF-1R) were examined in skeletal muscle of rats with chronic renal failure (CRF) and sham operated (SO), pair-fed controls. Acidemia was prevented in CRF rats with $\mathrm{NaHCO}_{3}$. Serum IGF-1 and skeletal muscle IGF-1 and IGF-1 mRNA were reduced in CRF rats. Dose-response studies revealed impaired stimulation of protein synthesis and suppressed inhibition of protein degradation by IGF-1 in epitrochlearis muscle of CRF rats. Neither IGF-1 analogues with low affinity to IGF binding proteins nor proteinase inhibitors obliterated the IGF-1 resistance. In CRF rats, skeletal muscle IGF-1R mRNA was increased; displacement ligand binding studies and affinity labeling of the IGF-1R $\alpha$ subunit indicated increased total skeletal muscle IGF-1R number with normal affinity. However, both autophosphorylation of the IGF-1R $\beta$ subunit (i.e., IGF-1R tyrosine kinase) and the IGF-1R tyrosine kinase activity towards exogenous insulin receptor substrate-1, a natural substrate for IGF-1R tyrosine kinase, were reduced in CRF rats. These data indicate that in skeletal muscle of CRF rats there is resistance to the IGF-1 effects on protein synthesis and degradation and decreased IGF-1 and IGF-1 mRNA levels; IGF-1R mRNA and number are increased; but activity of IGF-1R tyrosine kinase is impaired. This postreceptor defect may be a cause of the skeletal muscle resistance to IGF-1 in CRF. (J. Clin. Invest. 1996. 97:1064-1075.) Key words: IGF-1 receptor • uremia • tyrosine kinase $\bullet$ insulin receptor substrate $1 \cdot$ des-IGF-1
\end{abstract}

\section{Introduction}

Patients with chronic renal failure $(\mathrm{CRF})^{1}$ frequently are protein depleted (1). Protein deficiency in these individuals is evidenced not only by low serum albumin but also by reduced protein content in skeletal muscle (2), which is the largest compartment for body protein. Skeletal muscle atrophy and fibro-

Address correspondence to Joel D. Kopple, M.D., Division of Nephrology and Hypertension, Harbor-UCLA Medical Center, 1000 West Carson Street, Torrance, CA 90509. Phone: 310-222-3891; FAX: 310-782-1837.

Received for publication 24 February 1995 and accepted in revised form 22 November 1995.

J. Clin. Invest.

(C) The American Society for Clinical Investigation, Inc.

0021-9738/96/02/1064/12 \$2.00

Volume 97, Number 4, February 1996, 1064-1075 sis are not uncommon in CRF (3). Most studies in rats with experimental CRF demonstrate enhanced net skeletal muscle protein degradation, i.e., the sum of both protein synthetic and degradative rates; both increased protein degradation and/or reduced protein synthesis have been described $(4,5)$. $\mathrm{Re}$ ported causes for enhanced catabolism or reduced synthesis of skeletal muscle protein in CRF include acidemia, elevated glucocorticoids, and insulin resistance (for review see reference 6). No studies have examined whether there is resistance to the actions of insulin-like growth factor 1 (IGF-1) in skeletal muscle.

IGF-1 is an anabolic hormone that has about $50 \%$ structural homology with proinsulin (7). IGF-1 is synthesized in skeletal muscle as well as other tissues and acts on skeletal muscle primarily through the type 1 IGF receptor (IGF-1R). Like insulin, IGF-1 acts on skeletal muscle to stimulate cellular uptake of glucose and amino acids $(8,9)$ and enhance protein synthesis and suppress protein degradation (10). IGF-1 is necessary for skeletal muscle growth (11), and individuals with growth hormone receptor deficiency who also have low IGF-1 levels (i.e., Laron's dwarfism) have markedly decreased stature with essentially a proportionate reduction in skeletal muscle mass (12). IGF-1 may act in tissues in an autocrine or paracrine fashion, but may also function as an endocrine hormone (11). Several reports describe circulating inhibitors to IGF-1 (formerly referred to as somatomedin C) in patients with CRF $(13,14)$. Elevated levels of IGF binding proteins (IGFBPs), IGFBP fragments and small hemodialyzable compounds have been implicated as inhibitors of IGF-1 (14). Because of the potentially anabolic role of IGF-1 in skeletal muscle and other tissues, a number of investigators have begun to give recombinant growth hormone or recombinant human IGF-1 (rhIGF-1) to patients with $\operatorname{CRF}(15,16)$. The fact that there is no information on the actions of IGF-1 in skeletal muscle in CRF led us to investigate the effects of this hormone on protein turnover in this organ. We first evaluated the doseresponse relationship between rhIGF-1 and protein synthesis and degradation in skeletal muscle in CRF rats and shamoperated (SO), pair-fed rats. It was found that there was a suppressed skeletal muscle response to the anabolic effects of rhIGF-1 on both protein synthesis and degradation in CRF rats. Additional studies examined the potential mechanisms of this inhibition. The results indicate that a postreceptor defect

1. Abbreviations used in this paper: $B_{\max }$, maximum number of binding sites; $\mathrm{CRF}$, chronic renal failure; $\mathrm{IC}_{50}$, the inhibitor concentration for $50 \%$ displacement of tracer binding; IGF-1R, IGF-1 receptor; IGFBP, IGF binding protein; IRS-1, insulin receptor substrate-1; rhIGF-1, recombinant human IGF-1; SO, sham-operated; WGA, wheat germ agglutinin. 
of muscle IGF-1 receptor (IGF-1R) may be a cause of the resistance to the effects of IGF-1 on skeletal muscle protein turnover in CRF.

\section{Methods}

Reagents. $\left[{ }^{14} \mathrm{C}\right]$ Tyrosine was purchased from DuPont NEN (Boston, MA). ${ }^{125}$ I-IGF-1 (2,000 Ci/mmol) was obtained from Amersham Life Sciences (Arlington Heights, IL). Wheat germ agglutinin (WGA) was purchased from Vector Laboratories Inc. (Burlingame, CA). Disuccinimidyl suberate (DSS) was obtained from Pierce (Rockford, IL). Recombinant rat insulin receptor substrate-1 (IRS-1) and recombinant human IGF-2 (rhIGF-2) were obtained from Upstate Biotechnology Inc. (Lake Placid, NY). Insulin was purchased from Sigma Chemical Co. (St. Louis, MO). Electrophoresis and protein measurement reagents were obtained from Bio-Rad Laboratories (Hercules, CA). Recombinant human IGF-1 (rhIGF-1) was kindly provided by Dr. Hans-Peter Guler (Chiron Therapeutics, Emeryville, CA). DesIGF-1 was provided through the courtesy of Ross Clark, Ph.D. (Genentech Inc., South San Francisco, CA). LR 3 -IGF-1 was kindly provided by F. J. Ballard, Ph.D. (GroPep Pty Ltd, Adelaide, SA, Australia). Antisense RNA probes for detection of exon 1 and 2 IGF-1 mRNA, IGF-1R mRNA and $\beta$-actin mRNA were graciously provided by Dr. Dereck LeRoith, NIDDK, NIH, Bethesda, MD. All other chemicals were obtained from Sigma Chemical Co. (St. Louis, MO) unless specifically indicated otherwise.

Animals. Male Sprague-Dawley rats weighing 180-200 grams were studied. Animals were fed Purina rat chow containing $24 \%$ protein and tap water ad libitum for at least $3 \mathrm{~d}$ before undergoing surgery. CRF was induced by one-stage right nephrectomy and ligation of about three-fourths of the branches of the left renal artery. Shamoperated (SO) rats underwent laparotomy for a similar duration of time. After surgery, CRF rats were fed Purina rat chow (24\% protein) and tap water for drinking ad libitum. One SO rat was assigned randomly to each CRF rat. The SO rat was pair-fed the same amount of rat chow that was ingested by the CRF rat on the previous day and allowed to drink tap water ad libitum. The drinking water for the CRF rats contained $80 \mathrm{mM} \mathrm{NaHCO}$ to prevent acidemia. Body weight and serum creatinine in tail blood were measured every 3 and 7 d, respectively. After 21-22 d of pair-feeding, the animals were anesthetized; both epitrochlearis muscles were removed immediately and incubated for the measurement of either protein synthesis or protein degradation as described below. Aortic blood was obtained for the measurement of blood $\mathrm{pH}$ and $\mathrm{pCO}_{2}$. Gastrocnemius muscles and pooled hindlimb muscles were also collected, immediately dropped into liquid nitrogen and stored at $-80^{\circ} \mathrm{C}$ for subsequent extraction of total RNA and preparation of WGA-purified IGF-1 receptors (see below). Only the CRF rats that had a serum creatinine concentration of $1.1 \mathrm{mg} / \mathrm{dl}$ or greater and that survived the $21-22 \mathrm{~d}$ of pair-feeding were included in the studies; this constituted about $50-60 \%$ of the rats that underwent surgical reduction of kidney function.

Measurement of IGF-1 in serum and skeletal muscle. IGF-1 was extracted from serum and skeletal muscle and then measured by radioimmunoassay (RIA). Serum was acidified with $0.5 \mathrm{M} \mathrm{HCl}$ for $2 \mathrm{~h}$ at room temperature followed by separation from binding proteins with HPLC on an acetonitrile gradient in $0.1 \%$ trifluoroacetic acid using a C-18 peptide column (VYDAK, Hisperia, CA) as previously described (17). To extract IGF-1 from skeletal muscle, the procedures employed previously (17) were used with minor modifications. Briefly, tissue was homogenized in 10 volumes of acid-ethanol (ethanol:2 $\mathrm{M} \mathrm{HCl}=7: 1$ ); after incubation at room temperature for $30 \mathrm{~min}$, the homogenate was centrifuged at $12,000 \mathrm{~g}$ to remove the debris. The supernatant was neutralized with $0.855 \mathrm{M}$ Tris and precipitated at $-20^{\circ} \mathrm{C}$ overnight. The mixture was then centrifuged at $12,000 \mathrm{~g}$ for $30 \mathrm{~min}$ at $4^{\circ} \mathrm{C}$, and the supernatant was lyophilized. The lyophilate was reconstituted in acid-ethanol and reextracted again at $-20^{\circ} \mathrm{C}$ for $2 \mathrm{~h}$, centrifuged, and the supernatant was relyophilized. The second lyophilate was dissolved in assay buffer, cleaned by centrifugation, and the clear supernatant was used for RIA. The RIA for IGF-I in both serum and muscle was performed using a modification of the nonequilibrium technique as described by Furlanetto and coworkers (18) using ${ }^{125}$ I-labeled IGF-I and the IGF-I antiserum (UBK 487) provided by L.E. Underwood and J.J. Van Dyk (18), as previously described (17). Muscle protein was measured by the Bradford method (19). Data were expressed as either ng of IGF-1 per ml (serum) or ng of IGF-1 per gram protein (skeletal muscle).

Measurement of protein synthesis and degradation in epitrochlearis muscle. The measurement of muscle protein synthesis and degradation was based on the method of Clark and Mitch (20) as described previously (17). Briefly, the epitrochlearis muscle was incubated, without immobilization, in a shaking water bath at $37^{\circ} \mathrm{C}$ with KrebsHenseleit Ringer bicarbonate buffer (KRB, $\mathrm{pH} 7.4$, containing 10 $\mathrm{mM}$ glucose) supplemented with $0.1 \mathrm{mM}$ tyrosine, $0.5 \mu \mathrm{Ci}\left[{ }^{14} \mathrm{C}\right]$ tyrosine, and gassed with $95 \% \mathrm{O}_{2}$ and $5 \% \mathrm{CO}_{2}$. To this incubation medium were added different concentrations of rhIGF-1, two IGF-1 analogues (des-IGF-1 or LR $^{3}$-IGF-1), a mixture of five protease inhibitors (0.2 mM AEBSF [aminoethylbenzene sulfonylfluoride], $2 \mu \mathrm{M}$ leupeptin, $2 \mu \mathrm{M}$ pepstatin and aprotinin equivalent to 1 trypsin inhibitor $\mathrm{U} / \mathrm{ml}$ and $100 \mathrm{U} / \mathrm{ml}$ bacitracin) or vehicle, as indicated in Results and in the legends to the figures and tables. After $60 \mathrm{~min}$, the muscle was removed, blotted and reincubated for $2 \mathrm{~h}$ in a separate flask containing the same media. The muscle was then removed, homogenized in cold $10 \%$ trichloroacetic acid (TCA) and centrifuged. Proteins in the medium were also precipitated with $6 \%$ TCA. The pellet from the homogenized, precipitated muscle and the pellet from the medium were each washed with $6 \%$ TCA and then dissolved in $0.2 \mathrm{~N} \mathrm{NaOH}$. The radioactivity of the two redissolved pellets as well as of the supernatant from the medium was measured with a scintillation counter.

Total tyrosine in the supernatant from the medium was measured fluorometrically as described by Waalkes and Udenfriend (21). Protein synthesis was calculated by dividing the tyrosine radioactivity that was incorporated into muscle protein during the $2 \mathrm{~h}$ incubation by the specific activity of tyrosine in the medium (the ratio of the radioactive counts to the total tyrosine content in the supernatant of the deproteinized medium). The method for measuring protein degradation was similar to that for protein synthesis except that $0.5 \mathrm{mM}$ of cycloheximide, a protein synthesis inhibitor, was added, and neither labeled nor unlabeled tyrosine was included in the incubation media. After $2 \mathrm{~h}$ of incubation, the media was deproteinized with TCA, and the tyrosine content in the deproteinized medium was measured. Protein degradation was calculated from the rate of tyrosine accrual in the medium during the $2 \mathrm{~h}$ incubation. Both protein synthesis and degradation are expressed as nmol tyrosine per gram muscle wet weight per hour.

To examine whether IGF-1 was degraded in the incubation medium, the following protocol was used: epitrochlearis muscles from five pairs of CRF and SO, pair-fed rats were incubated with $300 \mathrm{ng} / \mathrm{ml}$ IGF-1 and $0.15 \mu \mathrm{Ci}{ }^{125} \mathrm{I}-\mathrm{IGF}-1$ for $90 \mathrm{~min}$ at $37^{\circ} \mathrm{C}$, with or without the five proteinase inhibitors indicated above. At the end of the incubation, fivefold concentrated Laemmli's sample buffer was added to the medium which was then separated on SDS-PAGE with a $15 \%$ polyacrylamide separating gel, transferred to $0.4 \mu \mathrm{m}$ Immobilon-P transfer membrane (Millipore) and visualized by autoradiography.

RNA extraction. Total RNA was extracted from gastrocnemius muscles by the guanidine thiocyanate isolation method of Chomczynski and Sacchi (22) using the TRI Reagent (Molecular Research Center, Cincinnati, OH). About $150 \mathrm{mg}$ tissue was homogenized in $1.5 \mathrm{ml}$ of TRI Reagent and centrifuged at $14,000 \mathrm{~g}$ for $5 \mathrm{~min}$. RNA in the clear supernatant was isolated according to the manufacturer's instructions and dissolved in Formazol (Molecular Research Center, Cincinnati, OH). The quantity of RNA was determined by absorbance at $260 \mathrm{~nm}$, and the quality was evaluated by visualizing the $18 \mathrm{~S}$ and $28 \mathrm{~S}$ ribosomal RNA after the total RNA was resolved in a $1 \%$ agarose/formaldehyde gel. 
Solution hybridization/RNase protection assay. The antisense RNA probe used for the identification of exon 1 and exon 2 IGF-1 mRNA and the probe for IGF-1 receptor mRNA have been described previously (23-25). The probes were synthesized and labeled using $50 \mu \mathrm{Ci}$ $\left.(10 \mathrm{mCi} / \mathrm{ml}){ }^{32} \mathrm{P}\right] \mathrm{UTP}$ and T7 (for IGF-1) and Sp6 (for IGF-1 receptor) polymerase with Riboprobe Gemini II System (Promega Corporation, Madison, WI) according to the manufacturer's instructions. After transcription, $1 \mu \mathrm{g}$ of DNase I, $8 \mu \mathrm{g}$ of tRNA, and $1 \mu \mathrm{l}$ of 200 $\mathrm{mM}$ vanadyl-ribonucleoside complex were added. The mixture was incubated for $15 \mathrm{~min}$ at $37^{\circ} \mathrm{C}$ and extracted with $0.5 \mathrm{vol}$ of phenol and $1 \mathrm{vol}$ of chloroform. The antisense RNA probe for $\beta$-actin was synthesized and labeled using T7 polymerase and $5 \mu \mathrm{Ci}$ of $\left[{ }^{32} \mathrm{P}\right] \mathrm{UTP}$. The solution hybridization/RNase protection assay was performed as described by Lowe et al. (24) with minor modifications. RNA samples were brought to a volume of $23.2 \mu \mathrm{l}$ with deionized formamide and added directly to the assay mixture without reprecipitation to avoid variability in recovery of the RNA before hybridization. $20 \mu \mathrm{g}$ of total RNA were hybridized for $16 \mathrm{~h}$ at $60^{\circ} \mathrm{C}$ with $1 \mu \mathrm{l}$ of probe mixture containing the antisense RNA probes for IGF-1 $\left(2 \times 10^{5} \mathrm{cpm}\right)$, IGF-1 receptor $\left(2 \times 10^{5} \mathrm{cpm}\right)$, and $\beta$-actin $\left(1 \times 10^{3} \mathrm{cpm}\right)$. The final concentration of the hybridization mixture was $75 \%$ formamide, $20 \mathrm{mM}$ Tris, $\mathrm{pH} 7.5,1 \mathrm{mM}$ EDTA, $\mathrm{pH}$ 8.0, $0.4 \mathrm{M} \mathrm{NaCl}$, and $0.1 \%$ SDS. After hybridization, samples were digested with RNase A at $40 \mu \mathrm{g} / \mathrm{ml}$ and RNase T1 at $2 \mu \mathrm{g} / \mathrm{ml}$ for $1 \mathrm{~h}$ at $30^{\circ} \mathrm{C}$. Protected hybrids were extracted with phenol/chloroform, precipitated with ethanol, and separated on an $8 \%$ polyacrylamide $/ 8 \mathrm{M}$ urea denaturing gel. The amount of each protected fragment was quantified by autoradiography and scanning densitometry.

Preparation of wheat germ agglutinin (WGA)-purified receptors. WGA-purified receptors were prepared from the snap frozen hindlimb muscle as reported previously (25) with minor modifications. All procedures were performed at $0-4^{\circ} \mathrm{C}$. Approximately one gram of muscle was homogenized in 4 vol ice-cold buffer $\mathrm{A}$ ( $\mathrm{pH} 7.6$, containing $50 \mathrm{mM}$ Hepes, $150 \mathrm{mM} \mathrm{NaCl}, 1 \%$ Triton $\mathrm{X}-100,1 \mathrm{mM}$ bacitracin, $1 \mathrm{mM}$ phenylmethylsulfonyl fluoride and aprotinin equivalent to 1 trypsin inhibitor unit/ml buffer). The homogenate was centrifuged at $10,000 \mathrm{~g}$ for $10 \mathrm{~min}$. The resultant supernatant was slowly stirred for 90 min with a mini-magnetic bar to solubilize the receptors and was centrifuged at 200,000 $\mathrm{g}$ for $60 \mathrm{~min}$. The supernatant was applied to a WGA-agarose affinity column that was pre-equilibrated thoroughly in buffer $\mathrm{B}(\mathrm{pH} 7.6$, containing $50 \mathrm{mM}$ Hepes, $150 \mathrm{mM} \mathrm{NaCl}$ and $0.1 \%$ Triton X-100). The eluate was reapplied to the column four additional times. After the column was washed with at least 100 bed vol of buffer B, the bound receptors were eluted in the glycoprotein fraction with buffer $\mathrm{C}$ (buffer B supplemented with $0.45 \mathrm{M} \mathrm{N}$-acetylglucosamine) and concentrated using an ultrafilter with a molecular weight cutoff of 10,000 daltons (Fisher Scientific, Pittsburgh, PA). The protein content was measured according to Bradford (19). Muscle samples from each CRF and pair-fed SO rat were always processed at the same time to obtain comparable receptor yields.

To determine whether the percent recovery of the IGF-1 receptor from WGA was similar in CRF and SO rats, the pellet and the supernatant after the 200,000 $\mathrm{g}$ centrifugation and the eluates from the WGA affinity columns in preparations from five pairs of CRF and SO, pair-fed rats were incubated with ${ }^{125}$ I-IGF-1 with or without 25 $\mathrm{nM}$ of unlabeled IGF-1 added. The specific binding of ${ }^{125}$ I-IGF-1 was calculated by subtracting the bound ${ }^{125}$ I-IGF-1 in the assay with unlabeled IGF-1 from the bound ${ }^{125}$ I-IGF-1 in the assay with no unlabeled IGF-1 added.

Receptor-ligand binding assay. Hormone binding assays were carried out in soft polyethylene microcentrifuge tubes in duplicate or triplicate. $20 \mu \mathrm{g}$ of WGA-purified protein were incubated in buffer B, in a total volume of $200 \mu \mathrm{l}$, with $50 \mathrm{pM}^{125}$ I-labeled IGF-1 in the absence or presence of various concentrations of unlabeled hormones as indicated in Results. After incubation for $16 \mathrm{~h}$ at $4^{\circ} \mathrm{C}$, the binding reaction was stopped by adding $100 \mu \mathrm{l}$ ice-cold $0.3 \% \gamma$-globulin and $300 \mu \mathrm{l}$ of $25 \%$ polyethylene glycol 8000 (PGE 8000) in buffer B. The tubes were incubated for $15 \mathrm{~min}$ at $4^{\circ} \mathrm{C}$ and then centrifuged for $5 \mathrm{~min}$ at $14,000 \mathrm{~g}$. The supernatant was aspirated, and the resultant pellet was washed twice with $300 \mu \mathrm{l}$ cold $12.5 \%$ PGE 8000 . The tubes were then inverted and drained at room temperature for 15-20 min, and the tips containing the pellet were cut off and counted in a gammacounter. Nonspecific binding was estimated in the presence of $50 \mathrm{nM}$ unlabeled IGF-1 and accounted for $8-15 \%$ of total binding. The specific binding was determined as the difference between each individual binding value and the average nonspecific binding. The binding data were analyzed by Scatchard plots (27) using the LIGAND program to fit the binding curves and to calculate the dissociation constant $\left(K_{\mathrm{d}}\right)$ and the maximum number of binding sites $\left(B_{\max }\right) . B_{\max }$ was factored by the protein content in the WGA-purified receptor preparation.

Equalization of receptor number in the WGA-eluate derived from $C R F$ and $S O$ rats. In cross-linking studies and receptor tyrosine kinase studies (see below), the IGF-1 binding activities in the WGAeluate from CRF and SO controls were equalized and the WGA-eluate from CRF and SO rats containing equal IGF-1 binding activity was used for the comparison between the groups. Because the number of the IGF-1 receptors $\left(B_{\max }\right)$ was increased in the skeletal muscle of CRF rats but the binding affinity $\left(K_{\mathrm{d}}\right)$ of the muscle IGF-1 receptor in CRF rats was not different from SO controls (see Results), the following procedure was used to obtain equal amounts of IGF-1 specific binding in the WGA eluates from each pair of CRF and SO rats: ${ }^{125}$ I-IGF-1 binding per $15 \mathrm{ug}$ WGA eluate from a given pair of CRF and SO rats was determined in the presence of 0.5, 1.0, 3.0, 6.0, 12.5, and $50 \mathrm{nM}$ unlabeled IGF-1 in triplicate. Ratios of the specifically bound counts in samples derived from the CRF rat to those from the pair-fed SO control were determined at each unlabeled IGF-1 concentration; these ratios were averaged, and the mean value was used to calculate the relative number of IGF-1 receptors in the WGA eluates from this pair of CRF and SO rats. The calculation for equalizing the number of IGF-1 receptors in the WGA eluate from a SO rat to the receptor number in the WGA eluate from its paired CRF rat was achieved by multiplying the volume of the WGA eluate from the $\mathrm{CRF}$ rat by the mean ratio obtained as described above; the resulting number was the volume of the WGA eluate from the SO rat to be used.

IGF-1 receptor affinity labeling. WGA-purified receptors were covalently cross-linked to ${ }^{125}$ I-IGF-1 according to Massagué and Czech (28) with minor modifications. The WGA eluate from CRF and SO rats containing equal amounts of IGF-1 specific binding activity was incubated overnight at $4^{\circ} \mathrm{C}$ with $4 \mathrm{nM}^{125} \mathrm{I}$-IGF-1, in $60 \mu \mathrm{l}$ buffer $\mathrm{B}$, in the absence or presence of unlabeled hormones as indicated in Results. Freshly prepared disuccinimidyl suberate (DSS) in dimethyl sulfoxide was then added, at a dilution of 1:100, to a final concentration of $0.4 \mathrm{mM}$. After incubation for $30 \mathrm{~min}$ at $4^{\circ} \mathrm{C}$, the reaction was stopped by adding fivefold concentrated Laemmli's buffer (29) with or without $50 \mathrm{mM}$ dithiothreitol (DTT). The samples were boiled for $3 \mathrm{~min}$ and resolved by SDS-PAGE according to the method of Laemmli (29) in 7.5\% resolving gels with $4 \%$ stacking gels. The dried gel was autoradiographed with Kodak X-Omat film (Eastman Kodak Co., Rochester, NY).

Autophosphorylation of the IGF-1R $\beta$ subunit. WGA-purified muscle receptor proteins from $\mathrm{CRF}$ and SO, pair-fed rats containing equal IGF-1 binding activities were incubated overnight at $4^{\circ} \mathrm{C}$ in buffer B supplemented with $8 \mathrm{mM} \mathrm{MnCl}_{2}$ and $10 \mathrm{mM} \mathrm{MgCl}_{2}$ in a total volume of $60 \mu \mathrm{l}$ in the presence of different concentrations of unlabeled IGF-1 or insulin. The phosphorylation reaction was then initiated by adding $50 \mathrm{nM}$ of ATP and $2.5 \mu \mathrm{Ci}\left[\gamma_{-}{ }^{32} \mathrm{P}\right] \mathrm{ATP}$ and was allowed to continue for $20 \mathrm{~min}$ at $4^{\circ} \mathrm{C}$. The reaction was then terminated by the addition of fourfold concentrated Laemmli's reducing sample buffer and by boiling for $3 \mathrm{~min}$. The reaction mixture was separated by SDS-PAGE, and the magnitude of phosphorylation was measured by autoradiography and densitometry.

Assay of IGF-1 receptor tyrosine kinase activity towards exogenous substrate. The autophosphorylation of IGF-1 receptor $\beta$ subunit and phosphorylation of insulin receptor substrate-1 (IRS-1), a 
natural substrate for IGF-1 receptor tyrosine kinase (30), was measured according to a modification of the methods of Myers et al. (30), and Alexandrides and Smith (31). WGA-purified muscle receptor protein from $\mathrm{CRF}$ rats and pair-fed controls containing equal amounts of IGF-1 binding activity were incubated overnight at $4^{\circ} \mathrm{C}$ in buffer B supplemented with $8 \mathrm{mM} \mathrm{MnCl} 2$ and $10 \mathrm{mM} \mathrm{MgCl}_{2}$ in a total volume of $60 \mu \mathrm{l}$ with $25 \mathrm{nM}$ rhIGF-1. After addition of $1 \mu \mathrm{g}$ of recombinant rat IRS-1 and $2 \mathrm{mM}$ activated sodium orthovanadate, the mixture was incubated on ice for $20 \mathrm{~min}$. The phosphorylation reaction was then initiated by adding $50 \mathrm{nM}$ of ATP and $2.5 \mu \mathrm{Ci}\left[\gamma^{-32} \mathrm{P}\right] \mathrm{ATP}$ and was allowed to continue for $90 \mathrm{~min}$ at $4^{\circ} \mathrm{C}$. The reaction was terminated by the addition of fourfold concentrated Laemmli's sample buffer containing $50 \mathrm{mM}$ DTT followed by boiling for $3 \mathrm{~min}$. The samples were separated by SDS-PAGE. The gels were dried, autoradiographed with Kodak-Omat film and analyzed with densitometry. The ratios of the densitometry units of phosphorylated IRS-1 bands to the units of phosphorylated IGF- 1 receptor $\beta$ subunit bands were calculated as the standardized index of the receptor tyrosine kinase activity towards exogenous substrate. In other receptor tyrosine kinase activity assays, the phosphorylation of exogenous IRS-1 was measured when the concentration of the $\beta$ subunit (i.e., receptor tyrosine kinase) was equalized between the CRF and SO rats. The equalization of receptor tyrosine kinase concentration was achieved by trial and error and was confirmed by demonstrating equal densities of the bands representing the autophosphorylated IGF-1R $\beta$ subunits. These assays were carried out with or without IGF-1, insulin or IRS-1 present in the assay buffer.

Statistical Analyses. All analyses for statistical significance were performed with the StatView statistical software package (BrainPower Inc., Calabasas, CA). Statistical significance between groups of data was analyzed by the non-paired Student's $t$ test (e.g., measurement of protein synthesis and degradation during incubation with rhIGF-1; $K_{\mathrm{d}}, B_{\max }$ and densitometry measurements). Evaluation of statistical significance among several groups was carried out by ANOVA (i.e., comparison of protein synthesis or degradation with rhIGF-1 vs. des-IGF-1, LR ${ }^{3}$-IGF-1 and rhIGF-1 with proteinase inhibitors). The variance of the values is given as the standard error of the mean (SEM). Statistical significance is taken as $P<0.05$.

\section{Results}

Characteristics of the CRF and sham-operated, pair-fed rats. Characteristics of the rats are shown in Table I. Most of these data were obtained from the first 30 to 40 pairs of CRF and SO rats studied. 3 wk after surgery the serum creatinine of the CRF rats was $1.18 \pm 0.06 \mathrm{mg} / \mathrm{dl}$ as compared with $0.33 \pm 0.01$ $\mathrm{mg} / \mathrm{dl}$ in the SO, pair-fed rats $(P<0.001)$. The body weights of the CRF rats $(200 \pm 11$ grams) were significantly lower than in the SO rats ( $256 \pm 28$ grams). At the time of killing, there was no difference in blood $\mathrm{pH}$ and $\mathrm{pCO}_{2}$ between the CRF rats and SO, pair-fed controls; this lack of difference was probably due to the $\mathrm{NaHCO}_{3}$ added to the drinking water of the CRF rats. IGF-1 levels in serum and in pooled hindlimb skeletal muscle in the CRF rats were $170.3 \pm 16.4 \mathrm{ng} / \mathrm{ml}$ and $4.22 \pm 1.03$ $\mathrm{ng} /$ grams, respectively. These values were significantly lower than in the SO rats $(410.4 \pm 49.3 \mathrm{ng} / \mathrm{ml}$ in serum and $6.93 \pm 1.41$ $\mathrm{ng} /$ grams in muscle, respectively, $P<0.001$ for each comparison). The basal protein synthesis rate (i. e., the values obtained from the muscle not incubated with any rhIGF-1) in epitrochlearis muscle of the CRF rats $(24.0 \pm 2.1 \mathrm{nmol}$ Tyr/grams per hour) was significantly lower, by $22 \%$, than that of SO, pairfed rats $(30.8 \pm 2.4 \mathrm{nmol} \mathrm{Tyr} / \mathrm{grams}$ per hour, $P<0.05)$. In contrast, the basal protein degradation rate in the epitrochlearis muscle of the CRF rats $(234.4 \pm 13.8 \mathrm{nmol}$ Tyr/grams per hour) was increased by $78 \%$ in comparison to SO rats $(131.7 \pm 8.4$ nmol Tyr/grams per hour, $P<0.001)$.

Effects of rhIGF-1 on protein synthesis and degradation in epitrochlearis muscle of $C R F$ and $S O$, pair-fed rats. To elucidate whether there was a difference between CRF and SO rats in the anabolic effects of rhIGF-1 on skeletal muscle protein synthesis and degradation, the dose-response relationship of rhIGF-1 on protein turnover in CRF rats and their SO, pairfed controls was determined. The two epitrochlearis muscles from each rat were isolated. One muscle was randomly assigned to be incubated with vehicle and the another was incubated with a given concentration of rhIGF-1, ranging from 25 to $500 \mathrm{ng} / \mathrm{ml}$ in the incubation medium. The effects of rhIGF-1 on skeletal muscle protein synthesis and degradation are presented as the absolute value of the epitrochlearis muscle incubated with the specified concentration of rhIGF-1 (Fig. 1, $A$ and $B$ ) or the percentage change calculated as the difference in the response of the two muscles from the same rat divided by the response of the muscle incubated with vehicle (Fig. 1, $C$ and $D$ ). As shown in Fig. 1, there was a rather linear doseresponse relationship in the epitrochlearis muscle of SO rats in which the protein synthesis rose and protein degradation fell as the concentrations of rhIGF-1 increased. In the SO rats, the peak increase in protein synthesis was $67 \pm 2.3 \%$ above the baseline at a rhIGF-1 concentration of $400 \mathrm{ng} / \mathrm{ml}$ in the incubation medium; the maximum suppression of protein degradation was $43.5 \pm 4.19 \%$ less than the baseline at the rhIGF-1 concentration of $500 \mathrm{ng} / \mathrm{ml}$. The effects of rhIGF-1 on protein synthesis and degradation in CRF rats were markedly attenu-

Table I. Characteristics of the CRF Rats and the Sham-operated (SO), Pair-Fed Rats

\begin{tabular}{|c|c|c|c|c|}
\hline & CRF rats & SO rats & $n$ & $P$ \\
\hline Serum creatinine $(\mathrm{mg} / \mathrm{dl})$ & $1.18 \pm 0.06$ & $0.33 \pm 0.01$ & 35 & $<0.01$ \\
\hline Body weight (grams) & $200 \pm 11$ & $256 \pm 28$ & 35 & $<0.01$ \\
\hline Arterial blood $\mathrm{pH}$ & $7.39 \pm 0.003$ & $7.40 \pm 0.003$ & 15 & NS \\
\hline Arterial blood $\mathrm{pCO}_{2}(\mathrm{mmHg})$ & $43.2 \pm 0.7$ & $41.6 \pm 0.4$ & 15 & NS \\
\hline Serum IGF-1 (ng/ml) & $170.3 \pm 16.4$ & $410.4 \pm 49.3$ & 10 & $<0.001$ \\
\hline Muscle IGF-1 (ng/gram) & $4.22 \pm 1.03$ & $6.93 \pm 1.41$ & 10 & $<0.01$ \\
\hline Protein synthesis (nmol Tyr/grams per hour) & $24.0 \pm 2.1$ & $30.8 \pm 2.4$ & 12 & $<0.05$ \\
\hline Protein degradation (nmol Tyr/grams per hour) & $234.4 \pm 13.8$ & $131.7 \pm 8.4$ & 12 & $<0.01$ \\
\hline
\end{tabular}

Data are the mean \pm SEM. Measurements were made after pair-feeding the rats for $21-22 \mathrm{~d}$ after surgery. $n$, Number of pairs of CRF and sham operated, pair-fed rats on which the measurement was made. NS, Not significantly different. 

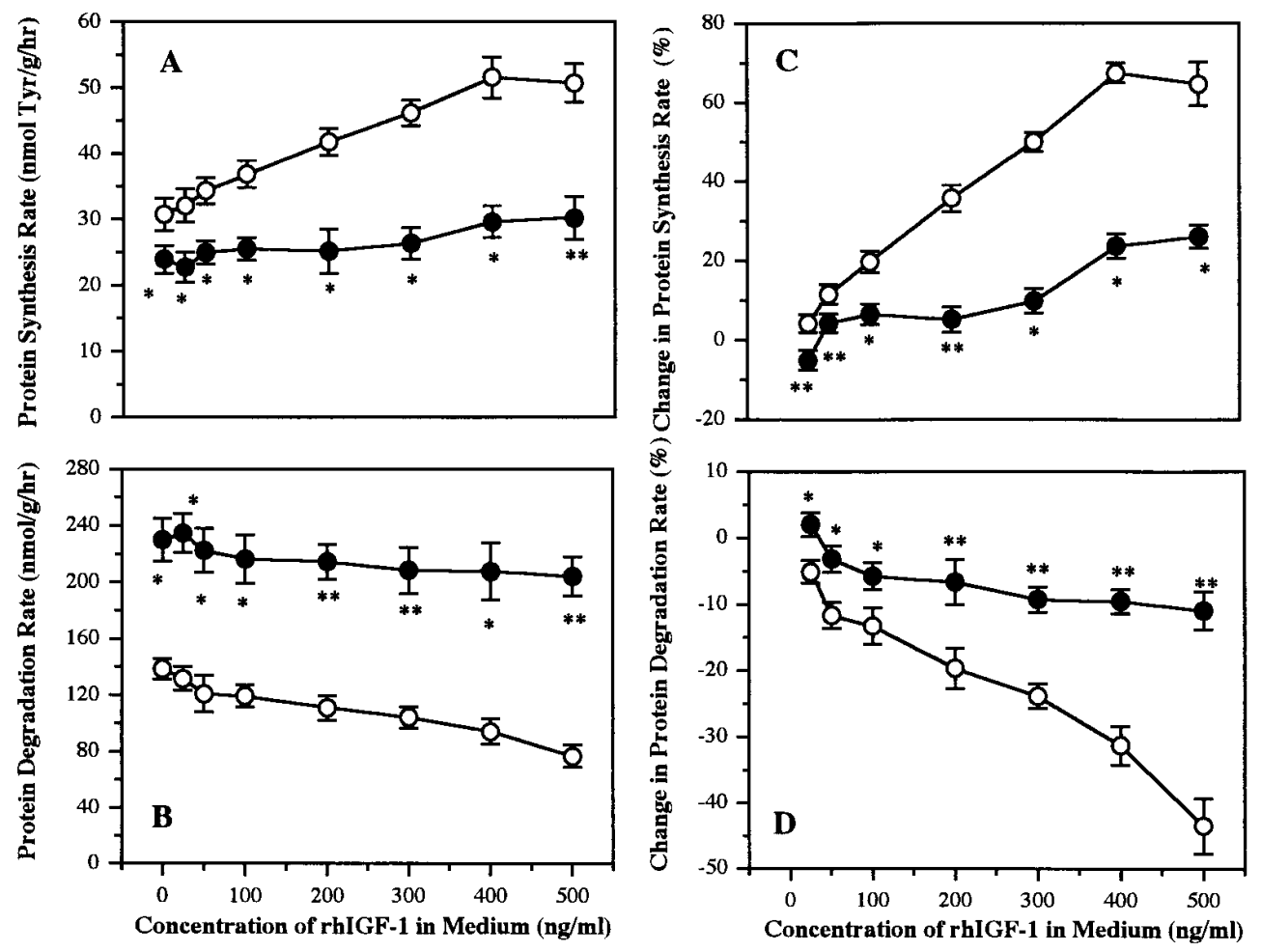

Figure 1. Dose-response relationship of the effects of rhIGF-1 on protein synthesis $(A$ and $C)$ and protein degradation $(B$ and $D$ ) in epitrochlearis muscle of CRF and SO, pair-fed rats. The two epitrochlearis muscles from each rat were separated. One was randomly assigned to incubation with vehicle and the other with different concentrations of rhIGF-1, as indicated. Muscle protein synthesis and degradation rates were measured and calculated as described in Methods. $A$ and $B$ show the absolute values for protein synthesis $(A)$ and degradation $(B)$ obtained from the muscles incubated with different concentrations of rhIGF-1. $C$ and $D$ show the percent changes in protein synthesis and degradation induced by incubation with rhIGF-1 calculated as the difference between the response of the two muscles from the same rat divided by the response of the muscle incubated with vehicle. Each point repre-

sents the mean \pm SEM of seven separate measurements. tions were carried out with the nonpaired $t$ test.

CRF rats; $(\bigcirc)$ SO rats. $* P<0.01,{ }^{* *} P<0.001 \mathrm{CRF}$ vs. SO rats. Statistical calcula-

ated as compared to their SO pair-fed controls (Fig. 1). The enhancement in epitrochlearis muscle protein synthesis induced by the various concentrations of rhIGF-1 in CRF rats was only 25 to $44 \%$ of that in SO rats. Similarly, the suppressive effects of the different concentrations of rhIGF-1 on protein degradation in epitrochlearis muscle from CRF rats were only 15 to $42 \%$ of those found in SO rats.

The effects of IGF-1 analogues and the influence of proteinase inhibitors on epitrochlearis muscle protein metabolism in $C R F$ and SO rats. IGFBPs in plasma and tissues are important physiological modulators and regulators of the actions of IGF-1 (32). Since plasma concentrations of some IGFBPs and IGFBP fragments are elevated in CRF and the accumulated IGFBPs and IGFBP fragments may display increased total binding capacity for rhIGF-1 (14), it is possible that the attenuated effects of rhIGF-1 on skeletal muscle protein turnover in CRF rats could be due to excessive binding of rhIGF-1 to the IGFBPs or IGFBP fragments in the incubated epitrochlearis muscles. Des-IGF-1 and LR ${ }^{3}$ IGF-1 are two IGF-1 analogues that have markedly reduced binding affinities to IGFBPs (33). Epitrochlearis muscles were therefore incubated with $40 \mathrm{nM}$ des-IGF-1, $40 \mathrm{nM} \mathrm{LR}^{3}$ IGF-1, or $40 \mathrm{nM}$ rhIGF-1 to assess whether the IGF-1 analogues with reduced protein binding affinity induced the same increase in protein synthesis and suppression in protein degradation in the CRF rats as compared to the SO controls. In addition, it is possible that muscle proteinases might degrade rhIGF-1 more avidly in CRF rats vs. SO rats. Therefore, the effect on epitrochlearis muscle protein synthesis and degradation of adding a mixture of five different proteinase inhibitors (see Methods) to the incubation media si- multaneously with the addition of rhIGF-1 was compared in $\mathrm{CRF}$ rats and $\mathrm{SO}$ rats.

In SO rats, des-IGF-1 and LR $^{3}$-IGF-1 increased protein synthesis in epitrochlearis muscle slightly more than equimolar quantities of rhIGF-1 $(P<0.05$, Fig. $2 A)$; only LR ${ }^{3}$-IGF-1 suppressed protein degradation more than rhIGF-1 (Fig. $2 B$ ). In CRF rats, $\mathrm{LR}^{3}$ IGF-1 but not des-IGF-1, increased protein synthesis and suppressed protein degradation slightly more than rhIGF-1 (Fig. 2). There was no effect of adding five proteinase inhibitors on rhIGF-1 enhanced protein synthesis or suppressed protein degradation in either the CRF rats or SO, pair-fed controls (Fig. 2). What is perhaps most relevant is that neither the IGF-1 analogues nor the mixture of proteinase inhibitors abolished or even reduced the attenuated effects of rhIGF-1 on skeletal muscle protein synthesis or degradation in the CRF rats. The possibility that IGF-1 was degraded in the incubation medium was also examined as follows: After completion of the incubation with epitrochlearis muscle, ${ }^{125} \mathrm{I}-\mathrm{IGF}-1$ and unlabeled rhIGF-1 in the medium was separated with a $15 \%$ polyacrylamide gel and autoradiographed as described in Methods. In both the CRF and SO rats, no radioactivity was found except in the IGF-1 bands (data not shown).

IGF-1 $m R N A$ and IGF-1 receptor $m R N A$ levels in skeletal muscle of $C R F$ and $S O$ rats. In skeletal muscle of the CRF and SO rats, two protected bands were detected when the total RNA was hybridized with the exon 1 and 2 derived IGF- 1 antisense RNA probe (Fig. 3) as has been previously reported in nonazotemic rats $(23,24)$. The major protected band has a size of about $428 \mathrm{bp}$. The 428-bp size of this band suggests that it is the IGF-1 mRNA initiated at the start site 3 in exon $1(23,24)$. 

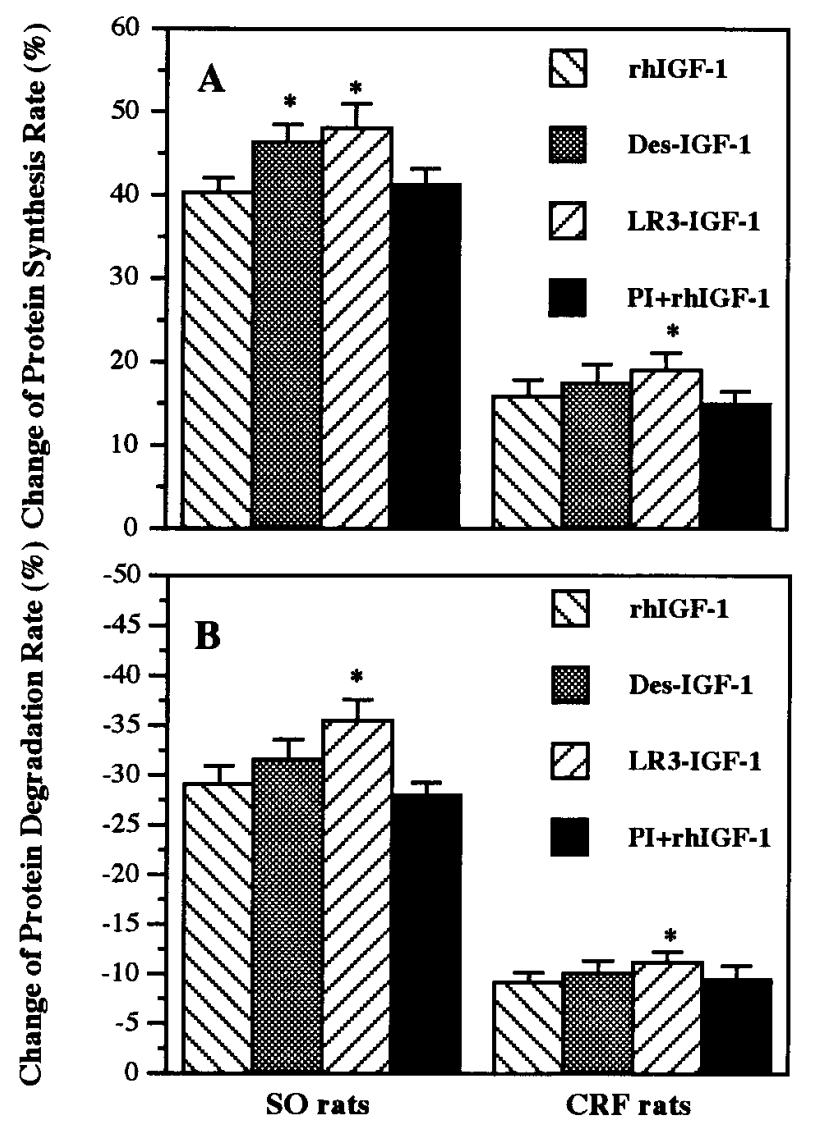

Figure 2. The effects of IGF-1 analogues with low binding affinity to IGF binding proteins (Des-IGF-1 and LR ${ }^{3}$ IGF-1) and the influence of proteinase inhibitors on the attenuated actions of rhIGF- 1 on protein synthesis $(A)$ and degradation $(B)$ in epitrochlearis muscle of $\mathrm{CRF}$ and $\mathrm{SO}$ rats. One of the two epitrochlearis muscles from each rat was randomly assigned to be incubated with vehicle and the other with $40 \mathrm{nM}$ des-IGF-1 (des-IGF-1), $40 \mathrm{nM} \mathrm{LR}^{3}$ IGF-1 (LR ${ }^{3}$ IGF-1), $40 \mathrm{nM}$ rhIGF-1(rhIGF-1), or $40 \mathrm{nM}$ rhIGF-1 in combination with five proteinase inhibitors $(0.2 \mathrm{mM}$ AEBSF [aminoethylbenzene sulfonylfluoride], $2 \mu \mathrm{M}$ leupeptin, $2 \mu \mathrm{M}$ pepstatin, 1 trypsin inhibitor $\mathrm{U} / \mathrm{ml}$ aprotinin, and $100 \mathrm{U} / \mathrm{ml}$ bacitracin (PI+rhIGF-1). Muscle protein synthesis and degradation rates were measured as described in Methods. Data are expressed as the difference between the response of the two muscles from the same rat incubated with rhIGF-1 or IGF-1 analogues and vehicle multiplied by 100 , and divided by the response of the muscle incubated with vehicle. Each point represents the mean \pm SEM of six separate measurements. Statistical calculations were carried out with ANOVA. ${ }^{*} P<0.05$ vs. $40 \mathrm{nM}$ rhIGF-1. $P I$, proteinase inhibitors.

The second protected band, which is fainter, has a size of about $210 \mathrm{bp}$ and is considered to be the IGF-1 mRNA initiated at the start site 4 in exon $1(23,24)$. Densitometry readings indicate that the 428 -bp band comprised $>70 \%$ of the two IGF-1 mRNA bands identified. When total skeletal muscle RNA from the CRF and SO rats was hybridized with the IGF-1 receptor antisense RNA probe, one protected band with a size of about 265 bp was observed (Fig. 3), as has been previously found in nonazotemic rats (25). The CRF rats displayed a decrease in skeletal muscle levels of both IGF-1 mRNA species and an increase in IGF-1 receptor mRNA levels in skeletal muscle as compared to SO, pair-fed rats (Fig. 3). Scanning densitometry analyses revealed that the skeletal

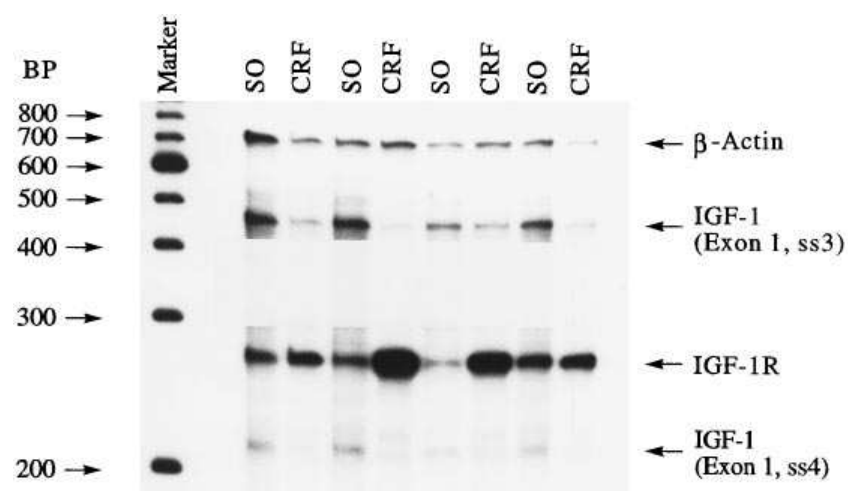

Figure 3. Example of an autoradiogram of the solution hybridization/ RNase protection assay of IGF-1 mRNA and IGF-1 receptor mRNA in skeletal muscle of CRF and SO rats. 20- $\mu$ g aliquots of total RNA extracted from gastrocnemius muscle of $\mathrm{CRF}$ and SO rats were hybridized with antisense RNA probes for IGF-1, IGF-1 receptor and $\beta$-actin as described in Methods. The arrows to the right indicate the protected mRNA species. The size of the protected IGF-1 receptor mRNA band is 265 bases. The IGF- 1 mRNA probe gave two protected bands. The band of 428 bases corresponds to the IGF-1 mRNA initiated at the start site 3 (ss3) in exon 1 . The band of 210 bases represents the IGF- 1 mRNA species initiated at the start site 4 (ss4) in exon 1. The arrows to the left indicate the base pair sizes of the 100 bp DNA ladders. Four identical assays were performed using total RNA samples from different pairs of CRF and SO rats, and the same results were obtained.

muscle levels of the IGF-1 mRNA initiated at the start site 3 in exon 1 and the IGF-1 mRNA initiated at the start site 4 in exon 1 in CRF rats were only $36 \pm 3.2 \%$ and $32 \pm 3.0 \%$ of those detected in SO rats, respectively, and the IGF-1 receptor mRNA level in skeletal muscle of CRF rats was $266 \pm 12.3 \%$ of the SO rats (Fig. 4).

IGF-1 receptor number and binding affinity in skeletal muscle of CRF and SO rats. Muscle IGF-1 receptor number and binding affinity in CRF and SO rats were measured by ligand-binding assay using WGA-purified IGF-1 receptors from pooled hindlimb muscles of CRF and SO rats. Scatchard analysis of the binding data revealed a single high affinity IGF-1 binding site in skeletal muscle of both CRF and SO rats. The regression lines derived from the binding data of CRF and SO rats are parallel (Fig. 5). In SO rats, the maximum IGF-1 binding number $\left(B_{\max }\right)$ and the dissociation constant $\left(K_{\mathrm{d}}\right)$ were $4.0 \pm 0.25 \mathrm{nmol} / \mathrm{mg}$ and $1.73 \pm 0.26 \mathrm{nM}$, respectively (Table II). $\mathrm{CRF}$ rats displayed a markedly increased $B_{\max }(9.78 \pm 0.49$ $\mathrm{nmol} / \mathrm{mg})$ as compared to SO rats $(P<0.001)$. However, the binding affinity $\left(K_{\mathrm{d}}\right)$ of the skeletal muscle IGF-1 receptor in CRF rats was not significantly different from that in SO rats (Table II). To further characterize the receptors responsible for the binding of ${ }^{125} \mathrm{I}-\mathrm{IGF}-1$ and its binding affinity, displacement binding assays of the binding of ${ }^{125} \mathrm{I}-\mathrm{IGF}-1$ to the WGA eluate were performed in the presence of increasing concentrations of unlabeled hormone in both CRF and SO rats. Binding of ${ }^{125}$ I-IGF- 1 to the WGA eluate derived from the hindlimb muscle of SO rats was most potently displaced by unlabeled rhIGF-1 and less potently by unlabeled rhIGF-2; unlabeled insulin had much less effect on IGF-1 binding. Similar findings were observed in CRF rats. Table II shows the calculated $\mathrm{IC}_{50}$ values (inhibitor concentration for $50 \%$ displace- 


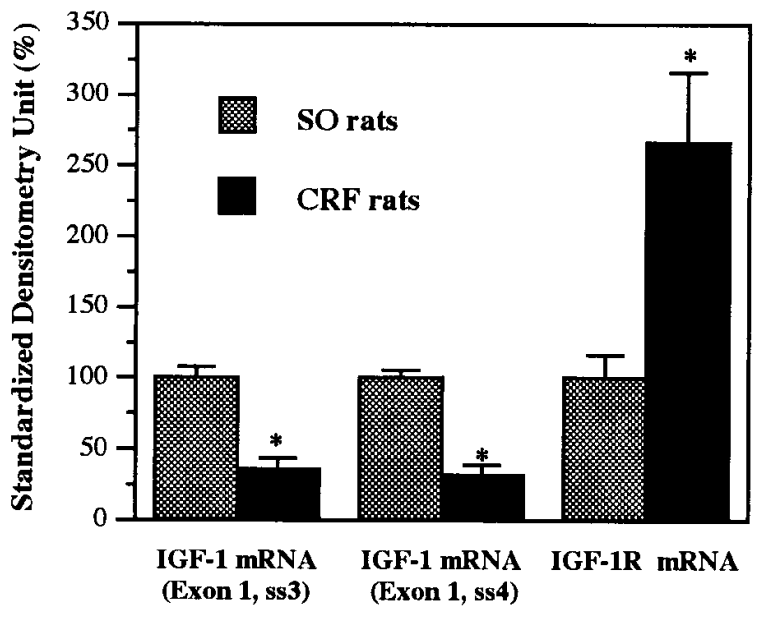

Figure 4. Scanning densitometry analysis of the protected mRNA bands for IGF-1 and IGF-1 receptor in gastrocnemius muscle from $\mathrm{CRF}$ and $\mathrm{SO}$, pair-fed rats. Data are the mean \pm SEM of four separate solution hybridization/RNase protection assays. The densitometry values for IGF-1 mRNA and IGF-1 receptor mRNA were standardized by dividing the densitometry values of IGF-1 mRNA and IGF-1 receptor mRNA by the value for $\beta$-actin mRNA. The standardized densitometry units of SO rats were arbitrarily defined as $100 \%$. Statistical calculations were carried out with the nonpaired $t$ test. $* P<$ 0.001 vs. SO rats. ss 3 , start site 3 . ss 4 , start site 4 .

ment of tracer binding) for these unlabeled hormones. In SO rats, unlabeled rhIGF- 1 had a $\mathrm{IC}_{50}$ of $0.396 \pm 0.02 \mathrm{nM}$; the $\mathrm{IC}_{50}$ for unlabeled rhIGF-2 and insulin were about 10-fold $(3.8 \pm 0.23 \mathrm{nM})$ and 500 -fold $(191 \pm 28 \mathrm{nM})$ greater, respectively, than that of unlabeled rhIGF-1. The $\mathrm{IC}_{50}$ values for these unlabeled hormones were not significantly different between the CRF rats and SO rats (Table II).

To document that the percent recovery of the IGF-1 receptor was similar in the two groups of rats, partially purified IGF-1 receptors from skeletal muscle were obtained from five pairs of CRF and SO, pair-fed rats. The ${ }^{125} \mathrm{I}-\mathrm{IGF}-1$ specific binding to the pellet and supernatant, obtained after the centrifugation at $200,000 \mathrm{~g}$, and in the final receptor preparation indicates that the extraction of the IGF-1 receptor from skeletal muscle homogenate was similar in the CRF and SO rats. The ${ }^{125}$ I-IGF-1 binding in the pellet was not different (P:NS) in the CRF vs. SO rats, $1.76 \pm 0.64$ vs. $2.24 \pm 0.96 \mathrm{cpm} / \mu \mathrm{g}$, respectively. ${ }^{125} \mathrm{I}-\mathrm{IGF}-1$ binding in the supernatant was significantly greater in the CRF rats, $105.4 \pm 10.2 \mathrm{cpm} / \mu \mathrm{g}$, as compared with the SO rats, $50.2 \pm 3.97, P<0.05$. In the final preparation, ${ }^{125} \mathrm{I}-\mathrm{IGF}-1$ binding was also greater in the CRF rats, $2362 \pm 231$ $\mathrm{cpm} / \mu \mathrm{g}$ vs. the $\mathrm{SO}$ animals, $1190 \pm 135, P<0.05$. The ratio of the ${ }^{125}$ I-IGF-1 binding in the final preparation to the supernatant was similar in the CRF rats, $23.2 \pm 3.4$, vs. the SO rats, 24.1 \pm 3.2 , P:NS. Thus, these data indicate that the percent recovery of the IGF-1 receptor in the CRF and SO rats was similar, and confirm our findings of increased receptor numbers in the skeletal muscle of the CRF rats.

Contamination of the partially purified receptor preparation with glycosylated IGFBPs could interfere with the receptor-ligand binding assays. To rule out this possibility, we subjected the receptor preparation from five pairs of CRF and SO, pair-fed rats to Western-ligand analysis with ${ }^{125} \mathrm{I}-\mathrm{IGF}-1$, utilizing purified IGFBP-3 and normal rat sera as positive con-

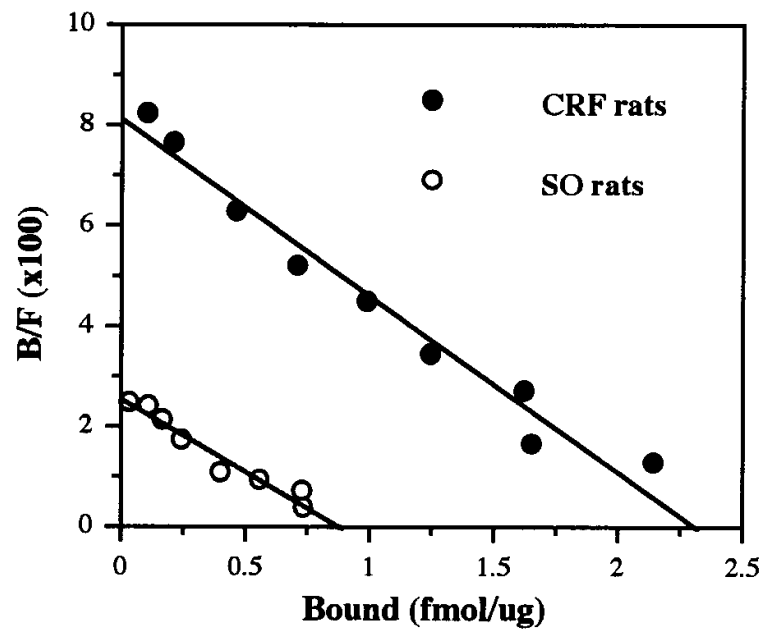

Figure 5. Scatchard analysis of ${ }^{125} \mathrm{I}-\mathrm{IGF}-1$ binding to solubilized, WGA-purified IGF-1 receptors in CRF and SO rats. WGA eluate (20 $\mu \mathrm{g}$ ) was incubated for $16 \mathrm{~h}$ at $4^{\circ} \mathrm{C}$ in buffer B with $50 \mathrm{pM}{ }^{125} \mathrm{I}$-IGF-1 and increasing concentrations of unlabeled rhIGF-1 (from 0.12 to 25 $\mathrm{nM}$ ) in a final volume of $200 \mu \mathrm{l}$. The receptor and bound IGF-1 were precipitated by sequential addition of $100 \mu \mathrm{l}$ of $0.3 \%$ bovine $\gamma$-globulin and $300 \mu \mathrm{l}$ of $25 \%$ polyethylene glycol. Nonspecific binding was estimated as the radioactivity precipitated in the presence of $50 \mathrm{nM}$ of unlabeled rhIGF- 1 and accounted for $8-15 \%$ of the total binding. Specific binding was determined as the difference between each individual binding value and the average nonspecific binding and normalized to the protein concentration in the WGA eluate. Points are means of six separate experiments in triplicate. For clarity, the SEM values are not shown; they range from 4 to $10 \%$ of the mean values.

trols. No IGFBP species were detected in $60 \mu \mathrm{g}$ of the receptor protein analyzed in the Western-ligand blot (data not shown). The absence of glycosylated IGFBPs in the receptor preparation is also evidenced by the results of the displacement receptor-ligand binding assays; the binding of ${ }^{125} \mathrm{I}-\mathrm{IGF}-1$ to the receptor preparation was completely displaced by high doses $\left(10^{-5} \mathrm{M}\right)$ of insulin, which has no binding affinity to IGFBPs (see above and Table II). These latter two experiments indicate that the finding of increased skeletal muscle IGF-1R numbers in the CRF rats could not be due to differences in the recovery of the receptor or to an increase in IGFBPs in the WGA eluates.

Affinity labeling (cross-linking) of ${ }^{125} I-I G F-1$ with WGA partially purified IGF-1 receptors in skeletal muscle of CRF and $S O$ rats. WGA eluates containing equal binding activities derived from pooled hindlimb muscle of $\mathrm{CRF}$ and $\mathrm{SO}$ rats were incubated with $4 \mathrm{nM}{ }^{125} \mathrm{I}-\mathrm{IGF}-1$ at $4^{\circ} \mathrm{C}$ for $16 \mathrm{~h}$ in the absence or presence of different concentrations of unlabeled IGF-1 or insulin and then cross-linked to the receptor-bound hormone by incubation with $0.4 \mathrm{mM}$ disuccinimidyl suberate (DSS). As shown in Fig. 6, in both CRF and SO rats one group of labeled bands appears on the autoradiogram when the cross-linked WGA eluate was resolved on SDS-PAGE in the absence of dithiothreitol (DTT) (Fig. 6, lanes $A$ and $G$ ). These bands may be composed of several bands with an apparent $M_{\mathrm{r}}>290,000$ daltons and have been reported previously to be the intact and partially proteolyzed native IGF-1 receptor complex (34). When the WGA eluate that was incubated with ${ }^{125}$ I-IGF-1 in the absence of unlabeled IGF-1 and insulin was affinity linked with DSS and electrophoresed in the presence of the disulfide 
Table II. Characteristics of the IGF-1 Receptor in Pooled Hindlimb Skeletal Muscle in CRF and Sham-Operated (SO), Pair-Fed Rats

\begin{tabular}{lccc}
\hline & CRF rats & SO rats & $P$ \\
\hline$B_{\max }(\mathrm{nmol} /$ mg protein) & $9.78 \pm 0.49$ & $4.00 \pm 0.25$ & $<0.001$ \\
$K_{\mathrm{d}}(\mathrm{nM})$ & $1.63 \pm 0.13$ & $1.73 \pm 0.26$ & NS \\
$\mathrm{IC}_{50}$ of rhIGF-1 $(\mathrm{nM})$ & $0.364 \pm 0.02$ & $0.396 \pm 0.02$ & NS \\
$\mathrm{IC}_{50}$ of rhIGF-2 $(\mathrm{nM})$ & $3.44 \pm 0.21$ & $3.83 \pm 0.23$ & NS \\
$\mathrm{IC}_{50}$ of insulin $(\mathrm{nM})$ & $227 \pm 31$ & $191 \pm 28$ & NS
\end{tabular}

Binding of ${ }^{125}$ IGF-1 to WGA eluates $(20 \mu \mathrm{g})$ derived from CRF and SO rats was carried out as described in Methods, in the absence or presence of unlabeled hormones (0.1-50 nM of rhIGF-1, 0.1-500 nM of rhIGF-2 or $1 \mathrm{nM}$ to $10 \mu \mathrm{M}$ of insulin). The LIGAND program was used to fit the displacement binding curves and to compute the characteristic parameters of the IGF-1 receptor. The $B_{\max }$ and $K_{\mathrm{d}}$ were deduced from the rhIGF-1 displacement binding data. The $\mathrm{IC}_{50}$ values were calculated from the respective competition binding data. Each value represents the mean \pm SEM of separate experiments performed in six pairs of CRF and SO rats in duplicate or triplicate. NS, Not significantly different. Statistical comparisons were performed with the nonpaired $t$ test.

reducing agent, DTT, in both CRF and SO rats two groups of affinity-labeled species are present on the autoradiogram (Fig. 6 , lanes $B$ and $H$ ). One group of intensely labeled bands appear in the $M_{\mathrm{r}}=140,000$ dalton region of the gel and has been denoted as the $\alpha$ subunit of the IGF-1 receptor (28). The other group actually consists of two labeled species with apparent $M_{\mathrm{r}}$ of about 275,000 and 235,000 daltons, respectively, and may correspond to the IGF-1 receptor subunits that have been cross-linked to each other, i.e., the $\alpha \alpha$ dimer and the $\alpha \beta$ dimer, as reported by others (34). In SO rats, $25 \mathrm{nM}$ unlabeled IGF-1 partially and $100 \mathrm{nM}$ unlabeled IGF-1 completely displaced the 140,000, 275,000 and 235,000 dalton species (lanes $C$ and $D$ ), whereas unlabeled insulin had almost no effect on these bands even at concentrations of $500 \mathrm{nM}$ and $1 \mu \mathrm{M}$, respectively, (lanes $E$ and $F$ ). The abilities of the unlabeled hormones to displace the cross linking of ${ }^{125}$ I-IGF-1 to the WGA eluates from CRF rats did not differ from SO rats (lanes $I-L$ ).

Diminished autophosphorylation of the skeletal muscle IGF-1R $\beta$ subunit in CRF rats. We next examined whether there was an abnormality in the postreceptor signaling of the skeletal muscle IGF-1R in CRF rats. The first step was to measure the autophosphorylation of the IGF-1R $\beta$ subunit induced by incubating the receptors with rhIGF-1 or insulin (Fig. 7). As shown in Fig. 7 B, one major group of phosphorylated protein bands with an apparent $M_{\mathrm{r}}$ of 95,000 daltons is visualized. These bands are considered to be the phosphorylated $\beta$ subunits of the IGF-1R. In both CRF and SO, pair-fed rats, autophosphorylation of the IGF-1R $\beta$ subunit was dosedependent, increasing with progressively rising rhIGF-1 concentrations. In CRF rats, the magnitude of receptor autophosphorylation was significantly lower $(P<0.05)$ at every IGF-1 concentration, averaging only 52 to $60 \%$ of the SO rats by densitometry analysis, even though the receptor protein assayed from CRF rats contained the same binding activity as the receptor preparation from their SO controls (Fig. 7, $A$ and $B$ ). Insulin, at 10 and $100 \mathrm{nM}$, induced little or no receptor autophosphorylation in the CRF and SO rats (Fig. $7 B$, lanes $E, F$, $K$, and $L$ ). Several other phosphorylated proteins are visualized in the autoradiogram when IGF-1 was added. The phos-

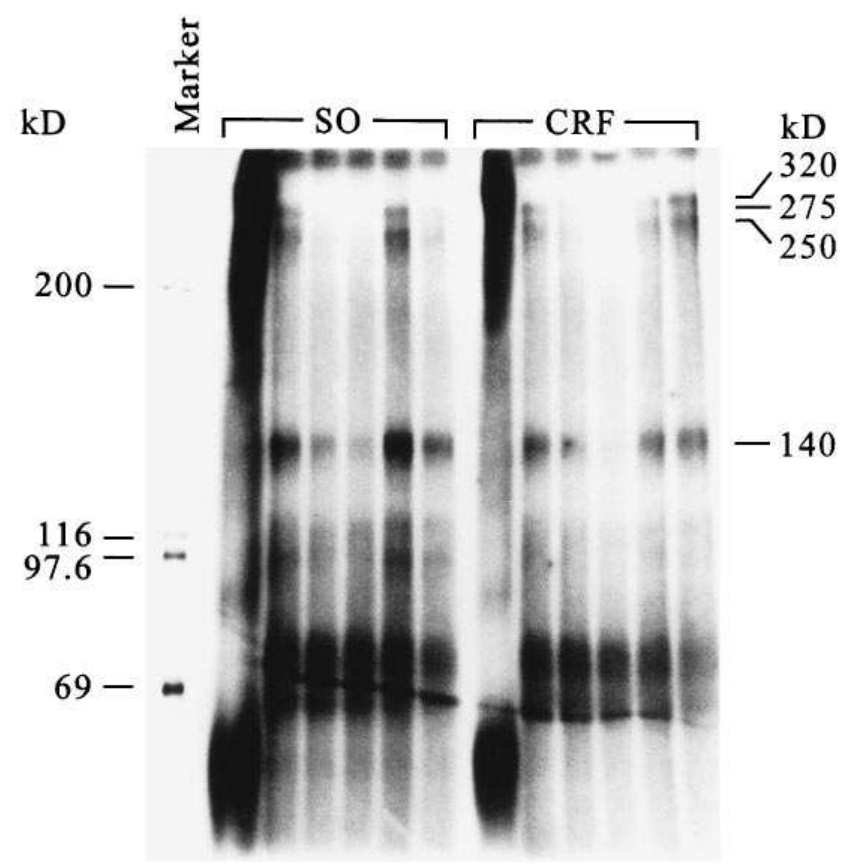

$\begin{array}{ll} & \text { A B C D E F G H I J K L } \\ \text { IGF-1 }(\mathrm{nM}) & --25100----25100-- \\ \text { Insulin }(\mu \mathrm{M})----0.51-- & -0.51 \\ \text { DTT } & -+++++-+++++\end{array}$

Figure 6. Affinity cross-linking of ${ }^{125} \mathrm{I}-\mathrm{IGF}-1$ to the WGA-purified receptors from skeletal muscle of CRF and SO rats. WGA eluates from $\mathrm{CRF}$ and $\mathrm{SO}$ rats containing equal binding activity were incubated with $4 \mathrm{nM}^{125} \mathrm{I}$-IGF-1 in buffer B at $4^{\circ} \mathrm{C}$ for $16 \mathrm{~h}$ at a total volume of 60 $\mu \mathrm{l}$ in the absence or presence of unlabeled IGF-1 and insulin as indicated. Cross-linking of the bound ${ }^{125}$ I-IGF-1 to the receptors was carried out by addition of $0.4 \mathrm{mM}$ disuccinimidyl suberate and subsequent incubation at $4^{\circ} \mathrm{C}$ for $30 \mathrm{~min}$. The reaction was stopped by adding fivefold concentrated Laemmli's sample buffer with or without $50 \mathrm{mM}$ dithiothreitol (DTT) as indicated and boiling for $3 \mathrm{~min}$. The samples were then separated by SDS-PAGE on a $7.5 \%$ resolving gel and a $4 \%$ stacking gel, and visualized by autoradiography. Affinity labeled $\alpha$ subunits of the IGF-1 receptor are indicated by an arrow to the right as the band with a $M_{\mathrm{r}}$ of 140,000 daltons. The IGF-1 receptor subunits that were cross-linked to each other, i.e., the $\alpha \alpha$ dimer and the $\alpha \beta$ dimer, are indicated by the arrows to the right as the bands with a $M_{\mathrm{r}}$ of 275,000 daltons and 235,000 daltons, respectively. Arrows to the left represent the $M_{\mathrm{r}}$ of the marker proteins.

phorylation of these proteins was not strongly correlated with the IGF-1 concentration, and their identity is not known.

Abnormal receptor tyrosine kinase activity of muscle IGF-1 receptor in $C R F$ rats. The next step was to examine muscle IGF-1 receptor tyrosine kinase activity towards exogenous insulin receptor substrate-1 (IRS-1), a natural substrate for the tyrosine kinase intrinsic to the $\beta$ subunit of the IGF-1 receptor (Fig. 8) (30). WGA-partially purified receptors containing equal specific IGF-1 binding activities from CRF and SO rats were activated by overnight incubation with unlabeled IGF-1 and then underwent a phosphorylation reaction in the presence of exogenous IRS-1. The reaction mixture was subsequently analyzed by SDS-PAGE. As shown in Fig. $8 \mathrm{~B}$, two species of labeled bands were visualized on the autoradiogram. One group of bands has a $M_{\mathrm{r}}$ of 95,000 daltons. These bands are considered to be the $\beta$ subunits of the IGF-1 receptor that 
A

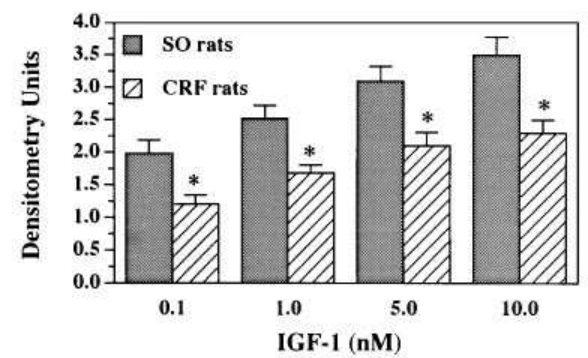

B

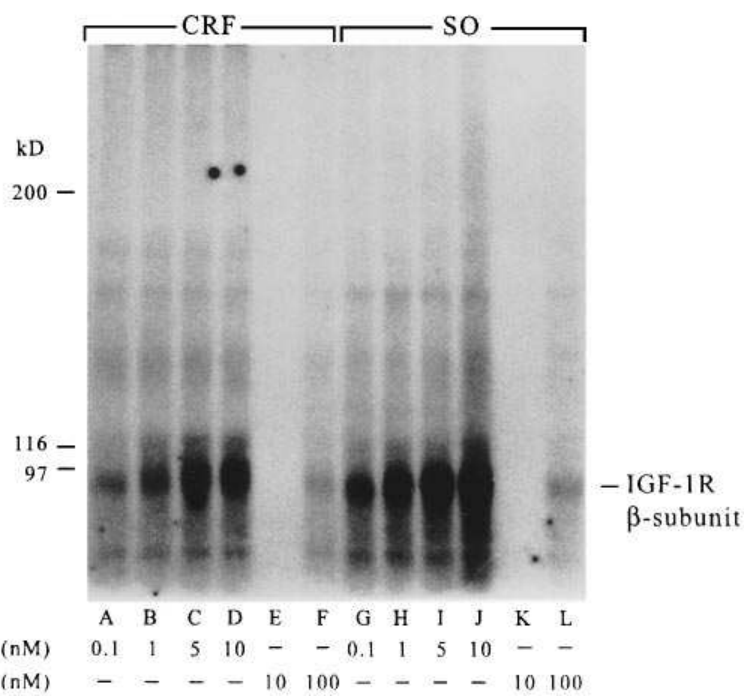

Insulin $(\mathrm{nM})$

$-\quad-\quad 10100-\ldots-10100$

Figure 7. Autophosphorylation of the IGF-1R $\beta$ subunit in skeletal muscle of CRF and SO, pair-fed rats. WGA-partially purified receptor containing equal binding activity from the pooled hindlimb muscle of three pairs of CRF and SO rats were incubated at $4^{\circ} \mathrm{C}$ for $16 \mathrm{~h}$ in $60 \mu \mathrm{l}$ of buffer $\mathrm{B}$ containing $8 \mathrm{mM} \mathrm{MnCl}_{2}$ and $10 \mathrm{mM} \mathrm{MgCl}_{2}$ with different concentrations of unlabeled rhIGF-1 as indicated in the Figure. The phosphorylation reaction was initiated by addition of $50 \mu \mathrm{M}$ ATP and $2.5 \mu \mathrm{Ci}\left[\gamma^{32} \mathrm{P}\right]$ ATP. After incubation at $4^{\circ} \mathrm{C}$ for $20 \mathrm{~min}$, the reaction was terminated by adding fivefold Laemmli's sample buffer and boiling for $3 \mathrm{~min}$. The assay mixture was then separated by SDSPAGE under reducing conditions and visualized by autoradiography. $(A)$ Densitometry analysis of the autoradiograms from the assays performed from the three pairs of CRF and SO rats: Values are mean \pm SEM. $* P<0.05$ vs SO rats by nonpaired $t$ test. $(B)$ Representative autoradiogram from a pair of CRF and SO rats, the horizontal line to the right indicates the phosphorylated IGF-1 receptor $\beta$ subunit, and the lines on the left indicate the molecular size of the marker proteins. Similar results were obtained in the assays from each of the three pairs of CRF and SO rats.

was autophosphorylated by the intrinsic receptor tyrosine kinase activated after the binding of IGF- 1 to the $\alpha$ subunit of the receptor (30). Another species of phosphorylated bands has a $M_{\mathrm{r}}$ of about 175,000 daltons. These bands represent the IRS-1 that was also phosphorylated by the activated intrinsic receptor tyrosine kinase $(30,31)$. The ratio of the density of the phosphorylated IRS-1 band to that of the autophosphorylated $\beta$ subunit of the IGF-1 receptor is taken as an index of the IGF-1R tyrosine kinase activity towards exogenous substrate (Fig. $8 A$ ). The mean value of this ratio in CRF rats $(0.52 \pm 0.06)$ was significantly lower than that in the SO, pairfed animals $(2.31 \pm 0.21, P<0.01)$ (Fig. $8 A)$.
A

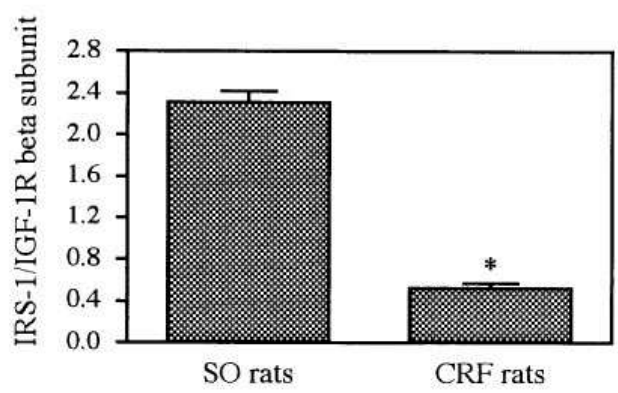

$\mathrm{B}$

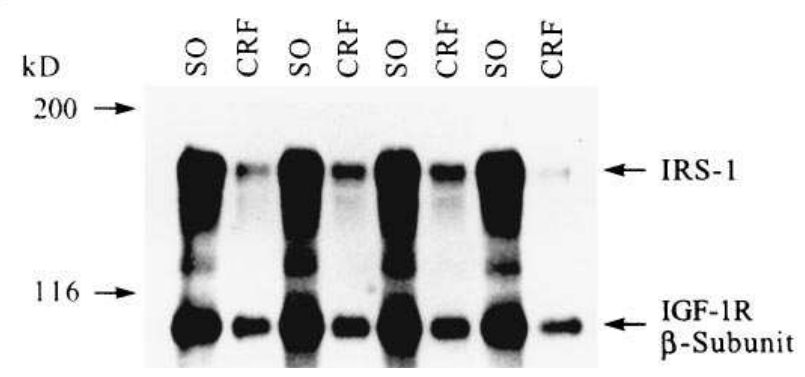

Figure 8. Phosphorylation assay for the skeletal muscle IGF-1 receptor tyrosine kinase activity towards exogenous insulin receptor substrate-1 (IRS-1) in CRF and SO, pair-fed rats. WGA eluates containing equal binding activities derived from the pooled hindlimb muscle of CRF and SO rats were incubation at $4^{\circ} \mathrm{C}$ for $16 \mathrm{~h}$ with $25 \mathrm{nM}$ unlabeled rhIGF-1 in $60 \mu \mathrm{l}$ of buffer B containing $8 \mathrm{mM} \mathrm{MnCl} \mathrm{M}_{2}$ and 10 $\mathrm{mM} \mathrm{MgCl} 2$. The phosphorylation reaction was initiated by addition of $50 \mu \mathrm{M}$ ATP, $2.5 \mu \mathrm{Ci}\left[\gamma^{-}{ }^{32} \mathrm{P}\right] \mathrm{ATP}$ and $1 \mu \mathrm{g}$ recombinant rat IRS-1. After incubation at $4^{\circ} \mathrm{C}$ for $90 \mathrm{~min}$, the reaction was terminated by adding fivefold Laemmli's sample buffer and boiling for $3 \mathrm{~min}$. The assay mixture was then separated by SDS-PAGE under reducing conditions and visualized by autoradiography. $(A)$ Densitometry analysis of the autoradiograms from the samples of the four pairs of CRF and $\mathrm{SO}$ rats shown in Fig. 8 B. The density of the IGF-1R $\beta$-subunit bands and the IRS-1 bands were standardized by correcting for the density readings obtained from the background in each lane. Results are presented as the ratio of the IRS- 1 bands to the IGF- 1 R $\beta$-subunit bands. Values are the mean \pm SEM. $* P<0.01$ vs SO rats by nonpaired $t$ test. $(B)$ Autoradiogram of the assay from the four pairs of rats. The arrows on the right indicate the autophosphorylated IGF-1 receptor $\beta$ subunit and the phosphorylated IRS-1. The arrows on the left indicate the molecular size of the marker proteins. Assays were also performed in another set of four pairs of CRF and SO rats with similar results.

Because the tyrosine kinase activity was lower in the skeletal muscle of the CRF rats (Fig. 8) and this might alter the kinetics of IRS-1 phosphorylation, we repeated these experiments using equal amounts of receptor tyrosine kinase activity in the CRF and SO rats (Fig. 9, see Methods). In addition, in some of these latter assays, IRS-1 was not added in order to ensure that the $175-\mathrm{kD}$ bands were exclusively IRS-1. Also to show that the activity was mediated by the IGF-1 receptor and not the insulin receptor, lanes with unlabeled insulin were included. As shown in Fig. 9, with equal amounts of tyrosine kinase activity added, the phosphorylation of IRS-1 was still reduced in the CRF rats (lanes $F$ vs. $A$ ). When IRS- 1 was not added to the assay, no phosphorylation of proteins in the 175$\mathrm{kD}$ region was observed (lanes $C$ and $H$ ). Both $10 \mathrm{nM}$ and 100 $\mathrm{nM}$ insulin had little or no stimulatory effects on the phosphor- 


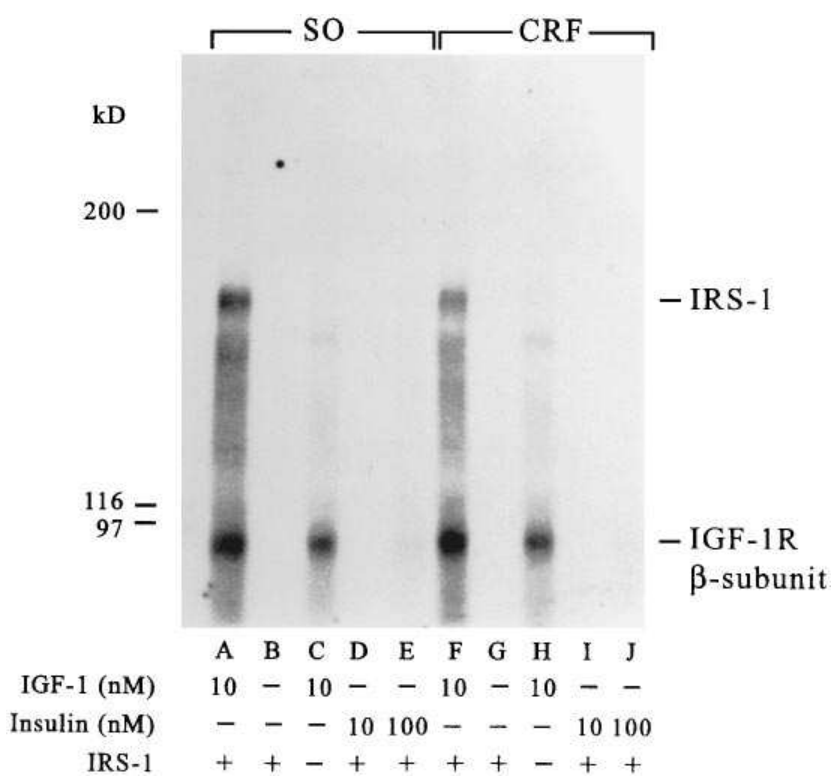

Figure 9. Phosphorylation of exogenous IRS-1 by intrinsic IGF-1R tyrosine kinase in skeletal muscle of CRF and SO rats. Phosphorylation of IRS-1 was assayed as described in Fig. 8 with the following modifications: the receptor tyrosine kinase activity in each lane from the CRF and SO rats was equalized as confirmed by the similar density of autophosphorylated IGF-1R $\beta$ subunit; in some lanes either rhIGF-1 (lanes $B$ and $G$ ) or IRS-1 (lanes $C$ and $H$ ) was not added or insulin was added at $10 \mathrm{nM}$ or $100 \mathrm{nM}$ (lanes $D, E$, $I$, and $J$ ). The molecular weight of the marker proteins and the location of the phosphorylated IGF-1R $\beta$ subunit and phosphorylated IRS-1 are indicated by horizontal lines. Similar results were obtained in assays from three pairs of CRF and SO, pair-fed rats.

ylation of either the IGF-1R $\beta$ subunit or IRS-1 in the CRF and SO rats (lanes $D, E, I$, and $J$ ).

\section{Discussion}

A number of studies indicate that animals with CRF display enhanced protein degradation and impaired protein synthesis in skeletal muscle $(6,7)$. In patients with CRF, skeletal muscle protein depletion is well described $(2,3)$. Although several causes for abnormal skeletal muscle protein metabolism in CRF have been proposed (6), all of the mechanisms have not been clearly elucidated. Since IGF-1 promotes protein accrual in skeletal muscle and there is resistance to the actions of IGF-1 in patients with CRF (34), it is possible that IGF-1 resistance is a cause of skeletal muscle protein depletion. Therefore, we examined the actions of IGF-1 in skeletal muscle of rats with $\mathrm{CRF}$. The CRF rats were given $80 \mathrm{mM} \mathrm{NaHCO}$ in the drinking water to prevent acidemia which may cause skeletal muscle protein degradation (4).

Our results indicate that over a wide range of rhIGF-1 concentrations $(25-500 \mathrm{ng} / \mathrm{ml})$, the epitrochlearis muscle of the SO rats showed a dose-responsive increase in protein synthesis and suppression of protein degradation (Fig. 1). The CRF rats, in contrast, displayed impaired stimulation of protein synthesis and suppression of protein degradation over this range of rhIGF-1 levels. The skeletal muscle resistance of CRF rats to the anabolic effects of rhIGF-1 on protein turnover is consistent with the observations from our studies in humans with
CRF (34). The acute fall in plasma insulin, C-peptide, cortisol, amino acids and glucose induced by an injection of two different doses of rhIGF-1 in chronic hemodialysis and peritoneal dialysis patients was significantly less than in normal adults. Notwithstanding these findings, repeated subcutaneous injections of pharmacological doses of rhIGF-1 does induce a more anabolic state in malnourished chronic peritoneal dialysis patients (16) and in rats with acute renal failure (17).

Both serum and skeletal muscle IGF-1 concentrations were reduced in the CRF rats (Table I). This also might contribute to their impaired protein synthesis and enhanced protein degradation in the skeletal muscle, which was observed even when no rhIGF-1 was added to the incubation medium (Fig. 1). Serum IGF-1 is mainly derived from the hepatic synthesis of IGF-1 (11). The decreased serum IGF-1 in CRF rats might be due to impaired hepatic IGF-1 synthesis. Chan et al. (35) reported that in CRF rats, liver IGF-1 mRNA was reduced by about $50 \%$ and displayed a blunted response to growth hormone injections. However, the decreased hepatic IGF-1 mRNA could be due to the reduced food intake of the CRF rats. Another potential cause for lower serum IGF-1 levels in $\mathrm{CRF}$ rats is the decreased renal IGF-1 synthesis, since the renal IGF-1 production is substantial (36).

The deficiency of muscle IGF-1 in CRF rats seems to be due to impaired IGF-1 synthesis, since skeletal muscle IGF-1 mRNA levels were reduced in CRF animals (Fig. 3 and 4). The mechanisms for the diminished skeletal muscle IGF-1 gene expression in CRF are not known. Growth hormone and insulin may stimulate the expression of IGF-1 mRNA in skeletal muscle in normal rats $(37,45)$, and resistance to both hormones occurs in CRF $(14,35,38)$. Intracellular calcium reciprocally regulates IGF-1 gene expression in cultured cells (39). In CRF, basal cytosolic calcium is increased in many tissues (40), and this might suppress the expression of skeletal muscle IGF-1 mRNA. Low nutrient intake and metabolic acidosis also downregulate IGF-1 gene transcription $(41,42)$. However, our SO rats were pair-fed to the CRF rats, and the CRF rats were fed $\mathrm{NaHCO}_{3}$ and were not acidemic (Table I).

The present study indicates that the impaired response of skeletal muscle to rhIGF-1 in CRF rats was not due to either excessive binding of rhIGF-1 to IGFBPs or to enhanced catabolism of rhIGF-1 (Fig. 2). Two IGF-1 analogues that have low binding affinities to IGFBPs, des-IGF-1 and LR ${ }^{3}-\mathrm{IGF}-1$, did not normalize the impaired response to rhIGF-1 in skeletal muscle of CRF rats. Also, addition of a combination of five different proteinase inhibitors to skeletal muscle did not normalize the actions of rhIGF-1 in these animals. Moreover, incubation of rhIGF-1 with skeletal muscle did not lead to detectable degradation products of IGF-1 in the media.

Because altered receptor binding capacity or function of the IGF-1 receptor (IGF-1R) could cause IGF-1 resistance, the IGF-1 receptor in skeletal muscle was studied. IGF-1 may interact with three distinct receptors (43): the IGF-1R, the IGF-2/mannose-phosphate receptor, and the insulin receptor. In skeletal muscle, where there is significant expression of the IGF-1R $(26,31)$, most of the acute metabolic effects of IGF-1 are mediated by the IGF-1 receptor $(9,44)$. The results of the current study show that the IGF-1R number in the WGA eluate, determined by the ligand binding assay, was increased in the CRF animals to 2.7 times the control values (Fig. 5, Table II). Since the skeletal muscle IGF-1R mRNA level was increased proportionately in the CRF rats, to about 2.5 times the 
value in the SO animals (Fig. 3 and 4), it seems likely that the increased IGF-1R number in CRF rats is due to the increased gene transcription for the IGF-1 receptor. The combination of up-regulated skeletal muscle IGF-1R mRNA and down-regulated IGF-1 mRNA levels observed in the CRF rats (Fig. 3 and 4) has also been described in fasted rats and rats with diabetes mellitus $(41,45)$. IGF-1 and insulin can each down-regulate the expression of IGF-1R mRNA in rat skeletal muscle in vivo (45). Thus, the decreased IGF-1 levels in skeletal muscle and sera of CRF rats and possibly the resistance to insulin in CRF (38) may contribute to the up-regulation of skeletal muscle IGF-1R mRNA and IGF-1R number.

Several lines of evidence indicate that the binding affinity of the skeletal muscle IGF-1R in the CRF rats was normal. The Scatchard plot curves derived from the ligand binding data of the CRF and SO rats are parallel (Fig. 5), and the dissociation constants $\left(K_{\mathrm{d}}\right)$ for the muscle IGF-1R from the CRF rats were not different from the SO rats (Table II). Furthermore, unlabeled rhIGF-1, rhIGF-2, and insulin displayed the same abilities to displace the specific binding of ${ }^{125} \mathrm{I}-\mathrm{IGF}-1$ to the WGA partially purified skeletal muscle IGF-1 receptor in CRF as compared to the SO rats; the inhibitor concentrations for $50 \%$ displacement of tracer binding $\left(\mathrm{IC}_{50}\right)$ for the three unlabeled hormones were not different between the CRF and the SO rats (Table II). Finally, the affinity cross-linking study further confirmed the similarity between the CRF and SO rats with regard to the displacement of the cross-linking of ${ }^{125}$ I-IGF- 1 to the $\alpha$ subunit of the skeletal muscle IGF-1R by unlabeled IGF-1 and insulin (Fig. 6).

The finding that the IGF-1R number was increased and receptor binding affinity was normal in skeletal muscle of CRF rats indicates that the total IGF-1R binding capacity in skeletal muscle was probably elevated in these rats. Thus, the possibility that the IGF-1 resistance was due to a postreceptor defect was explored. IGF-1 binds to the IGF-1 receptor at the $\alpha$ subunit of the receptor where it activates the tyrosine kinase intrinsic to the IGF-1R $\beta$ subunit (46). The activated receptor tyrosine kinase phosphorylates, on tyrosine residues, both the IGF-1R $\beta$ subunit (46) and several other intracellular proteins including insulin receptor substrate-1 (IRS-1, 30, 46). IRS-1 seems to be an important mediator protein in the signaling cascade induced by IGF-1 and insulin receptors. It is rapidly tyrosyl phosphorylated by IGF-1R tyrosine kinase and acts as a docking molecule which binds to and regulates the activity of other substrate proteins $(30,46)$. We therefore examined two aspects of the postreceptor signal transduction system for skeletal muscle IGF-1R: the autophosphorylation of the IGF-1R $\beta$ subunit and the activity of the IGF-1 receptor tyrosine kinase towards exogenous IRS-1. Both of these activities were impaired in the CRF rats (Figs. 7-9). At each concentration of rhIGF-1, the autophosphorylation of the $\beta$ subunit was reduced in the CRF rats as compared to the SO animals. The skeletal muscle IGF-1R tyrosine kinase activity towards exogenous IRS-1, measured as the ratio of the phosphorylation of exogenous IRS- 1 to the phosphorylation of IGF-1R $\beta$ subunit, was significantly reduced in the CRF rats (Figs. 8 and 9). Moreover, when the magnitude of the receptor tyrosine kinase autophosphorylation in the CRF and SO rats was adjusted to be similar, the phosphorylation of IRS- 1 was clearly reduced in the CRF rats (Fig. 9). These findings suggest that both the impaired autophosphorylation of the tyrosine kinase in the IGF-1 receptor and reduced phosphorylation of IRS-1 by
IGF-1R tyrosine kinase are causes of the diminished skeletal muscle response to IGF-1 in the CRF rats.

In summary, we observed skeletal muscle resistance to the anabolic effects of exogenous IGF-1 on protein metabolism in $\mathrm{CRF}$ rats. In skeletal muscle of CRF rats, protein synthesis is reduced and protein degradation is enhanced. The doseresponsive increase in protein synthesis and suppression in protein degradation induced by IGF-1 in CRF rats is markedly attenuated. There are decreased serum IGF-1 levels and, in skeletal muscle, reduced IGF-1 mRNA and the IGF-1 peptide and increased IGF-1R mRNA and IGF-1R number with normal binding affinity. Both autophosphorylation of the IGF-1R tyrosine kinase and activity of the IGF-1R tyrosine kinase towards exogenous IRS-1 are diminished in skeletal muscle of CRF rats. None of these abnormalities can be accounted for by acidemia or reduced nutrient intake. These abnormalities may contribute to the abnormal skeletal muscle protein metabolism that occurs in CRF rats.

\section{Acknowledgments}

Supported in part by the Baxter Extramural Grant Program, National Institutes of Health grant (M01-RR00425) and Ciba Geigy Corporation. Presented in part at the 26th and 27th Annual Meetings of the American Society of Nephrology, Boston, MA, November 14-17, 1993 and Orlando, FL, October 26-29, 1994.

\section{References}

1. Kopple, J.D. 1994. Effect of nutrition on morbidity and mortality in maintenance dialysis patients. Am. J. Kid. Dis. 24:1002-1009.

2. Guarnieri, G., G. Toigo, R. Situlin, L. Faccini, U. Coli, S. Landini, G. Bazzato, F. Dardi, and L. Campanacci. 1983. Muscle biopsy studies in chronically uremic patients: Evidence for malnutrition. Kid. Int. 24 (Suppl. 16) S187S193.

3. Ahonen, R.E. 1980. Light microscopic study of striated muscle in uremia. Acta Neuropathol. (Berlin). 49:51-55.

4. May, R.C., R.A. Kelly, and W.E. Mitch. 1987. Mechanisms for defects in muscle protein metabolism in rats with chronic uremia: influence of metabolic acidosis. J. Clin. Invest. 79:1099-1103.

5. Li, J.B., and S.J. Wassner. 1986. Protein synthesis and degradation in skeletal muscle of chronically uremic rats. Kidney Int. 29:1136-1143.

6. Mitch, W.E., C. Jurkovitz, and B.K. England. 1993. Mechanisms that cause protein and amino acid catabolism in uremia. Am. J. Kid. Dis. 21:91-95.

7. Rinderknecht, E., and R.E. Humbel. 1978. The amino acid sequence of human insulin-like growth factor I and its structural homology with proinsulin. J. Biol. Chem. 253:2769-2776.

8. Dohm, G.L., C.W. Elton, M.S. Raju, N.D. Mooney, R. DiMarchi, W.J. Pories, E.G. Flickinger, S.M. Atkinson, Jr., and J.F. Caro. 1990. IGF-1 stimulated glucose transport in human skeletal muscle and IGF-1 resistance in obesity and NIDDM. Diabetes. 39:1028-1032.

9. Yu, K.T., and M.P. Czech. 1984. The type I insulin-like growth factor receptor mediates the rapid effects of multiplication-stimulating activity on membrane transport system in rat soleus muscle. J. Biol. Chem. 259:3090-3095.

10. Harper, J.M.M., J.B. Soar, and P.J. Buttery. 1987. Changes in protein metabolism of ovine primary muscle cultures on treatment with growth hormone, insulin, insulin-like growth factor I or epidermal growth factor. J. Endocr. 112:87-96.

11. Gluckman, P.D., R.G. Douglas, G.R. Ambler, B.H. Breier, S.C Hodgkinson, J.B. Koea, and J.H.F. Shaw. 1991. The endocrine role of insulinlike growth factor I. Acta. Pediatr. Scand. (Suppl.) 372:97-105.

12. Savage, M.O., W.F. Blum, M.B. Ranke, M.C. Postel-Vinay, A.M. Cotterill, K. Hall, P.G. Chatelain, M.A. Preece, and R.G. Rosenfeld. 1993. Clinical features and endocrine status in patients with growth hormone insensitivity (Laron Syndrome). J. Clin. Endocrinol. Metab. 77:1465-1471.

13. Phillips, L.S., and J.D. Kopple. 1981. Circulating somatomedin activity and sulfate levels in adults with normal and impaired kidney function. Metabolism. 30:1091-1095.

14. Blum, W.F., M.B. Ranke, K. Kietzmann, B. Tönshoff, and O. Mehls. 1991. Growth hormone resistance and inhibition of somatomedin activity by excess of insulin-like growth factor binding protein in uremia. Pediatr. Nephrol. 5: $539-544$. 
15. Schulman, G., R.L. Wingard, R.L. Hutchison, P. Lawrence, and R.M. Hakim. 1993. The effects of recombinant human growth hormone and intradialytic parenteral nutrition in malnourished hemodialysis patients. Am. J. Kid. Dis. 21:527-534.

16. Peng, S., D. Fouque, and J.D. Kopple. 1993. Insulin-like growth factor 1 (IGF-1) causes anabolism in malnourished CAPD patients. J. Am. Soc. Nephrol. 4:414 (Abstr.)

17. Ding, H., J.D. Kopple, A. Cohen, and R. Hirschberg. 1993. Recombinant human insulin-like growth factor-I accelerates recovery and reduces catabolism in rats with ischemic acute renal failure. J. Clin. Invest. 91:2281-2287.

18. Furlanetto, R.W., L.E. Underwood, J.J. Van Wyk, and A.J. D'Ercole. 1977. Estimation of somatomedin-C levels in normals and patients with pituitary disease by radioimmunoassay. J. Clin. Invest. 60:648-657.

19. Bradford, M.M. 1976. A rapid and sensitive method for quantitation of microgram quantities of protein utilizing the principle of protein binding. Anal. Biochem. 72:248-254.

20. Clark, A.S., and W.E. Mitch. 1983. Comparison of protein synthesis and degradation in incubated and perfused muscle. Biochem. J. 212:649-653.

21. Waalkes, T.P., and S. Udenfriend. 1957. A fluorometric method for the estimation of tyrosine in plasma and tissues. J. Lab. Clin. Med. 50:733-736.

22. Chomczynski, P., and N. Sacchi. 1987. Single-step method of RNA isolation by acid guanidinium thiocyanate-phenol-chloroform extraction. Anal. Biochem. 162:156-159.

23. Adamo, M.L., H. Ben-Hur, C.T. Roberts, Jr., and D. LeRoith. 1991. Regulation of start site usage in the leader exons of the rat insulin-like growth factor-1 gene by development, fasting and diabetes. Mol. Endocrinol. 5:16771686.

24. Lowe, W.L., Jr., C.T. Roberts, Jr., S.R. Lasky, and D. LeRoith. 1987. Differential expression of alternative $5^{\prime}$ untranslated regions in mRNAs encoding rat insulin-like growth factor I. Proc. Natl. Acad. Sci. USA. 84:8946-8950.

25. Werner, H., M. Woloschak, M. Adamo, Z. Shen-Orr, C.T. Roberts, Jr., and D. LeRoith. 1989. Developmental regulation of the rat insulin-like growth factor I receptor gene. Proc. Natl. Acad. Sci. USA. 86:7451-7455.

26. Alexandrides, T., A.C. Moses, and R.J. Smith. 1989. Developmental expression of receptors for insulin, IGF-I and IGF-II in rat skeletal muscle. Endocrinology. 124:1064-1076.

27. Scatchard, G. 1949. The attractions of proteins for small molecules and ions. Ann. NY Acad. Sci. 51:660-672.

28. Massagué, J., and M.P. Czech. 1982. The subunit structures of two distinct receptors for insulin-like growth factors I and II and their relationship to the insulin receptor. J. Biol. Chem. 257:5038-5045.

29. Laemmli, U.K. 1970. Cleavage of structural proteins during the assembly of the head of bacteriophage T4. Nature (Lond.). 227:680-685.

30. Myers, M.G., Jr., X.J. Sun, B. Cheatham, B.R. Jachna, E.M. Glasheen, J.M. Backer, and M.F. White. 1993. IRS-1 is a common element in insulin and insulin-like growth factor-I signaling to the phosphatidylinositol 3 '-kinase. Endocrinology. 132:1421-1430.

31. Alexandrides, T.K., and R.J. Smith. 1989. A novel fetal insulin-like growth factor (IGF) I receptor: Mechanism for increased IGF I- and insulin- stimulated tyrosine kinase activity in fetal muscle. J. Biol. Chem. 264:1292212930.

32. Baxter, R.C., and J.L. Martin. 1989. Binding proteins for the insulin-like growth factors: structure, regulation and function. Prog. Growth Factor Res. 1: 49-68.

33. Tomas, F.M., S.E. Knowles, C.S. Chandler, G.L. Francis, P.C. Owens, and F.J. Ballard. 1993. Anabolic effects of insulin-like growth factor I (IGF-I) and an IGF-I variant in normal female rats. J. Endocrinol. 137:413-421.

34. Fouque, D., S.C. Peng, and J.D. Kopple. 1995. Impaired metabolic response to recombinant insulin-like growth factor-1 in dialysis patients. Kidney Int. 47:876-883.

35. Chan, W., K.C. Valerie, and J.C.M. Chan. 1993. Expression of insulinlike growth factor-1 in uremic rats: growth hormone resistance and nutritional intake. Kidney Int. 43:790-795.

36. D'Ercole, A.J., A.D. Stiles, and L.E. Underwood. 1984. Tissue concentrations of somatomedin C: further evidence for multiple sites of synthesis and paracrine or autocrine mechanisms of action. Proc. Natl. Acad. Sci. USA. 81: 935-939.

37. Isgaard, J., L. Carlsson, O.G.P. Isaksson, and J.O. Jansson. 1988. Pulsatile intravenous growth hormone $(\mathrm{GH})$ infusion to hypophysectomized rats increases insulin-like growth factor 1 messenger ribonucleic acid in skeletal tissues more effectively than continuous GH infusion. Endocrinology. 123:26052610 .

38. Cecchin, F., O. Ittoop, M.K. Sinha, and J.F. Caro. 1988. Insulin resistance in uremia: insulin receptor kinase activity in liver and muscle from chronic uremic rats. Am. J. Physiol. 254:E394-E401.

39. Hovis, J.G., T. Meyer, R.M. Teasdale, B.N. Albrecht, M.A. Yorek, and W.L. Lowe, Jr. 1993. Intracellular calcium regulates insulin-like growth factor-I messenger ribonucleic acid levels. Endocrinology. 132:1931-1938.

40. Massry, S.G., and G.Z. Fadda. 1993. Chronic renal failure is a state of cellular calcium toxicity. Am. J. Kid. Dis. 21:81-86.

41. Thissen, J.P., J.M. Ketelslegers, and L.E. Underwood. 1994. Nutritional regulation of the insulin-like growth factors. Endocrinol. Rev. 15:80-101.

42. Challa, A., W. Chan, R.J. Krieg, Jr., M.A. Thabet, F. Liu, R.L. Hintz, and J.C.M. Chan. 1993. Effect of metabolic acidosis on the expression of insulin-like growth factor and growth hormone receptor. Kidney Int. 44:1224-1227.

43. Rehler, M.N., and S.P. Nissley. 1990. Insulin-like growth factors; in Sporn MB, Roberts AB (eds): Peptide growth factors and their receptors. Springer-Verlag, New York. 263-368.

44. Rechler, M.M., and S.P. Nissley. 1985. The nature and regulation of the receptors for insulin-like growth factors. Annu. Rev. Physiol. 47:425-442.

45. Bornfeldt, K.E., A. Skottner, and H.J. Arnqvist. 1992. In-vivo regulation of messenger RNA encoding insulin-like growth factor-1 (IGF-1) and its receptor by diabetes, insulin and IGF-1 in rat muscle. J. Endocrinol. 135:203211.

46. Lamphere, L., and G.E. Lienhard. 1992. Components of signaling pathways for insulin and insulin-like growth factor-I in muscle myoblasts and myotubes. Endocrinology. 131:2196-2202. 